\title{
Graphitic Carbon Nitride/CdSe Quantum Dot/Iron Carbonyl Cluster Composite for Enhanced Photocatalytic Hydrogen Evolution
}

Li, Chuanshuai; Zou, Xianshao; Lin, Weihua; Mourad, Hassan; Meng, Jie; Liu, Yang; Abdellah, Mohamed; Guo, Meiyuan; Zheng, Kaibo; Nordlander, Ebbe

\section{Published in:}

ACS Applied Nano Materials

Link to article, DOI:

10.1021/acsanm.1c01096

Publication date:

2021

Document Version

Publisher's PDF, also known as Version of record

Link back to DTU Orbit

Citation (APA):

Li, C., Zou, X., Lin, W., Mourad, H., Meng, J., Liu, Y., Abdellah, M., Guo, M., Zheng, K., \& Nordlander, E. (2021). Graphitic Carbon Nitride/CdSe Quantum Dot/Iron Carbonyl Cluster Composite for Enhanced Photocatalytic Hydrogen Evolution. ACS Applied Nano Materials , 4(6), 6280-6289. https://doi.org/10.1021/acsanm.1c01096

\section{General rights}

Copyright and moral rights for the publications made accessible in the public portal are retained by the authors and/or other copyright owners and it is a condition of accessing publications that users recognise and abide by the legal requirements associated with these rights.

- Users may download and print one copy of any publication from the public portal for the purpose of private study or research.

- You may not further distribute the material or use it for any profit-making activity or commercial gain

- You may freely distribute the URL identifying the publication in the public portal 


\section{Graphitic Carbon Nitride/CdSe Quantum Dot/Iron Carbonyl Cluster Composite for Enhanced Photocatalytic Hydrogen Evolution}

Chuanshuai Li, Xianshao Zou, Weihua Lin, Hassan Mourad, Jie Meng, Yang Liu, Mohamed Abdellah, Meiyuan Guo, Kaibo Zheng,* and Ebbe Nordlander*

Cite This: ACS Appl. Nano Mater. 2021, 4, 6280-6289

Read Online

\section{ACCESS I}

Џlll Metrics \& More

Article Recommendations

Supporting Information

ABSTRACT: A g- $\mathrm{C}_{3} \mathrm{~N}_{4} / \mathrm{CdSe}$ quantum dot/ $\left[\mathrm{Fe}_{2} \mathrm{~S}_{2}(\mathrm{CO})_{6}\right]$ composite has been successfully constructed. The structure and chemical composition of the composite were investigated via, inter alia, transmission electron microscopy (TEM), Fourier transform infrared spectroscopy (FTIR), and X-ray photoelectron spectroscopy (XPS). The ability of the assembly to act as a photocatalyst for proton reduction to form hydrogen gas was studied. With visible light irradiation for $4 \mathrm{~h}$, the total $\mathrm{H}_{2}$ production catalyzed by the $\mathrm{g}$ $\mathrm{C}_{3} \mathrm{~N}_{4} / \mathrm{CdSe}$ quantum dot/ $\left[\mathrm{Fe}_{2} \mathrm{~S}_{2}(\mathrm{CO})_{6}\right]$ composite was found to be 9 times as high as a corresponding $\mathrm{CdSe} /\left[\mathrm{Fe}_{2} \mathrm{~S}_{2}(\mathrm{CO})_{6}\right]$ assembly and significantly higher than either the CdSe quantum dots or $\mathrm{g}-\mathrm{C}_{3} \mathrm{~N}_{4}$ alone. The $\mathrm{g}-\mathrm{C}_{3} \mathrm{~N}_{4}$ support/matrix was found to enhance the stability and efficiency of the CdSe

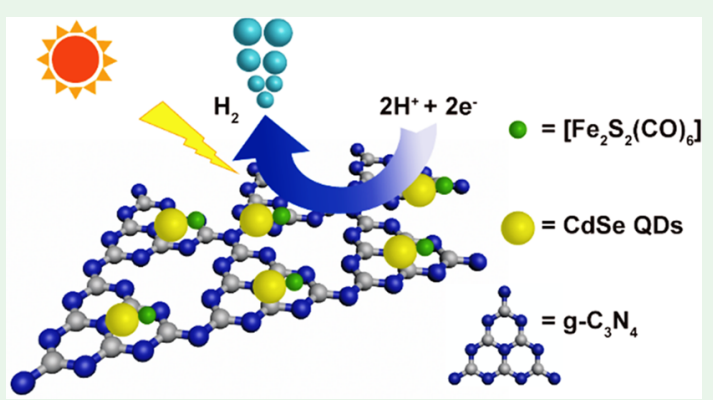
quantum dot/iron carbonyl cluster assembly in the photocatalytic hydrogen evolution process. Results from recycling tests showed that the $\mathrm{g}-\mathrm{C}_{3} \mathrm{~N}_{4} / \mathrm{CdSe}$ quantum $\operatorname{dot} /\left[\mathrm{Fe}_{2} \mathrm{~S}_{2}(\mathrm{CO})_{6}\right]$ composite is a sustainable and robust photocatalyst, maintaining the same activity after three cycles. The photoinduced charge carrier transfer dynamics in the $\mathrm{g}-\mathrm{C}_{3} \mathrm{~N}_{4} / \mathrm{CdSe}$ quantum dot/[Fe $\left.\mathrm{S}_{2}(\mathrm{CO})_{6}\right]$ composite system has been investigated by transient absorption (TA) and time-resolved photoluminescence (TRPL) spectroscopies. The spectroscopic results indicate efficient hole transfer from the valence band of the excited CdSe quantum dots to the molecular iron carbonyl clusters and from the defect state of the quantum dots to $\mathrm{g}-\mathrm{C}_{3} \mathrm{~N}_{4}$ in the $\mathrm{g}-\mathrm{C}_{3} \mathrm{~N}_{4} / \mathrm{CdSe}$ quantum dot/[Fe $\left.\mathrm{S}_{2}(\mathrm{CO})_{6}\right]$ composite, which significantly inhibits the recombination of photogenerated charge carriers in CdSe quantum dots and boosts the photocatalytic activity and stability for hydrogen evolution. Energy transfer from $\mathrm{g}_{-} \mathrm{C}_{3} \mathrm{~N}_{4}$ to the CdSe quantum dot/[Fe $\left.\mathrm{S}_{2}(\mathrm{CO})_{6}\right]$ assembly with a time constant of $0.7 \mathrm{~ns}$ also contributed to the charge transfer process.

KEYWORDS: photocatalytic proton reduction, ternary composite, graphitic carbon nitride, quantum dot, iron carbonyl cluster, charge transfer, energy transfer

\section{INTRODUCTION}

The generation of solar fuels and energy carriers via photocatalytic water splitting is currently subject to intense research efforts. Photocatalysis has been widely recognized as a potential scalable means for low-cost and environmentally benign hydrogen production from water, converting solar energy into a renewable green energy carrier. Since the initial studies on photoelectrocatalytic water splitting on $\mathrm{TiO}_{2}$ by Fujishima and Honda, ${ }^{1-6}$ intensive efforts have been made to achieve effective photocatalytic reduction of water into hydrogen driven by sunlight.

A classical artificial photosynthetic system utilizes photogenerated charges to drive the formation of chemical bonds. The separation of photogenerated electron-hole pairs to suppress charge recombination is essential to efficient photoreactions. ${ }^{5}$ Such systems include photocatalysts that can directly convert solar energy through photocatalytic water splitting (water photoelectrolysis), including $\mathrm{CdSe}, \mathrm{ZnO}$, and $\mathrm{MoS}_{2}{ }^{6}$. The catalytic activity of established semiconductor photocatalysts can also be drastically improved by their integration with co-catalysts or the formation of composites between semiconductors and other materials. ${ }^{7}$ The co-catalysts often consist of biomimetic complexes designed to reproduce essential features of the metal-containing active sites of hydrogenase enzymes, proteins that can catalyze both the forward and backward reaction $2 \mathrm{H}^{+}+2 \mathrm{e}^{-} \rightleftarrows \mathrm{H}_{2}{ }^{8-10}$ Cadmium selenide quantum dots show many advantages as photocatalysts, such as high extinction coefficients, tunability of size and size-dependent properties, and they may be coupled with hydrogenase mimics to form photocatalytic assemblies. ${ }^{11-13}$ Such water-soluble hybrid assemblies have the potential to boost photocatalytic activity for hydrogen generation (proton reduction). ${ }^{13-15}$ However, there is a

Received: April 22, 2021

Accepted: May 13, 2021

Published: June 9, 2021 
Scheme 1. Schematic Depiction of the Synthetic Procedure for the Preparation of a $\mathrm{g}_{-} \mathrm{C}_{3} \mathrm{~N}_{4} / \mathrm{CdSe}$ Quantum Dot/[Fe $\left.2 \mathrm{~S}_{2}(\mathrm{CO})_{6}\right]$ Composite (Assembly = CdSe Quantum Dot $/\left[\mathrm{Fe}_{2} \mathrm{~S}_{2}(\mathrm{CO})_{6}\right]$ Assembly $\left.{ }^{13}\right)^{a}$

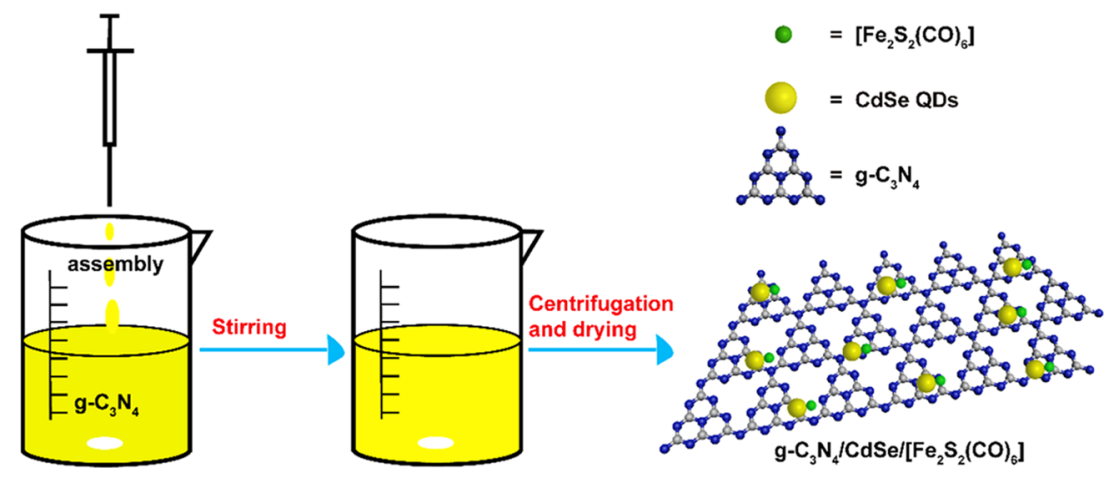

${ }^{a}$ N.B.: the individual constituents of the composite are not depicted to scale.

considerable risk that quantum dots or quantum dot/cocatalyst assemblies may aggregate and cause photocorrosion under light irradiation with consequent slow kinetics of interfacial charge transfer. ${ }^{16,17}$ Prevention of the decomposition of quantum dot/co-catalyst assemblies under light illumination and in acidic solutions constitutes a significant challenge.

The loading of nanoparticles into porous materials to generate a stable heterostructure is a strategy for the preparation of photocatalysts that are efficient and stable under such conditions. ${ }^{18-21}$ Graphitic carbon nitride $\left(\mathrm{g}-\mathrm{C}_{3} \mathrm{~N}_{4}\right)$ is a metal-free organic polymer semiconductor with twodimensional structure, a moderate band gap of $2.7-2.8 \mathrm{eV}$, and low cost of preparation. ${ }^{22}$ These features make g- $\mathrm{C}_{3} \mathrm{~N}_{4}$, e.g., two-dimensional g- $\mathrm{C}_{3} \mathrm{~N}_{4}$ sheets, promising catalysts or catalyst supports for heterogeneous hydrogen evolution. As support/ matrix, a g- $\mathrm{C}_{3} \mathrm{~N}_{4}$-based catalytic system can provide enhanced stability by protecting the active sites and functional groups on the surface of the quantum dots through surface passivation. Simultaneously, it can enable the formation of a Schottky junction (metal/semiconductor heterostructure) or a $\mathrm{p}-\mathrm{n}$ junction (semiconductor/semiconductor heterostructure), thus facilitating charge and energy transfer for catalysis. ${ }^{23-25}$ For example, heterostructured hybrids such as $\mathrm{SnO}_{2}-\mathrm{ZnO} / \mathrm{g}$ $\mathrm{C}_{3} \mathrm{~N}_{4}$ and $\mathrm{Au} / \mathrm{TiO}_{2}-\mathrm{g}-\mathrm{C}_{3} \mathrm{~N}_{4}$ exhibit enhanced photocatalytic hydrogen reduction under irradiation by visible light with outstanding cycling stability. ${ }^{26,27}$ Zhong et al. have constructed $\mathrm{CdSe}$ quantum dot/g- $\mathrm{C}_{3} \mathrm{~N}_{4}$ composites that significantly enhance photocatalytic hydrogen evolution activity compared with pure cadmium selenide quantum dots or carbon nitride, when a platinum complex (chloroplatinic acid $\left[\mathrm{H}_{3} \mathrm{O}\right]_{2}\left[\mathrm{PtCl}_{6}\right]$ ) was used as a co-catalyst. ${ }^{28}$ The enhanced hydrogen production was attributed to a synergism of excellent visible absorption and high charge separation efficiency in the CdSe quantum dot $/ \mathrm{g}-\mathrm{C}_{3} \mathrm{~N}_{4}$ heterostructures. ${ }^{28}$

Based on our previous studies of quantum dot/transitionmetal carbonyl cluster assemblies as photocatalysts for proton reduction, ${ }^{13}$ we were interested in achieving better stability of such assemblies through absorption/adsorption in or on a mesoporous solid. Loading of CdSe quantum dots or CdSe quantum dot/iron carbonyl assemblies on the carbon nitride sheet was expected to afford a stable, efficient, and robust nano-heterojunction structure. A two-dimensional g- $\mathrm{C}_{3} \mathrm{~N}_{4}$ nanosheet can fix CdSe quantum dots or a corresponding assembly and reduce agglomeration risk. Furthermore, such a heterostructure may also enhance charge transfer between carbon nitride and the quantum dots and thus contribute to improved photocatalytic hydrogen production. Here, we report the construction of a new ternary g- $\mathrm{C}_{3} \mathrm{~N}_{4} / \mathrm{CdSe}$ quantum dot/ iron carbonyl cluster composite for aqueous hydrogen evolution under visible light excitation. This composite has been shown to exhibit significant enhancement in hydrogen evolution efficiency and stability relative to the water-soluble CdSe quantum dot/iron carbonyl photocatalytic assembly. Transient absorption (TA) and time-resolved photoluminescence (TRPL) spectroscopies have been used to investigate the charge carrier transfer dynamics in the new composite. The spectroscopic results indicate efficient photoinduced hole transfer from the valence band of the excited CdSe quantum dots to the molecular iron complex, as well as transfer to g$\mathrm{C}_{3} \mathrm{~N}_{4}$ through the sub-band-gap defect states. This significantly inhibits the recombination of photogenerated charge carriers in the CdSe quantum dots and boosts the photocatalytic activity and stability for hydrogen production. At the same time, the energy transfer from $\mathrm{g}-\mathrm{C}_{3} \mathrm{~N}_{4}$ to the $\mathrm{CdSe}$ quantum dot/ $\left[\mathrm{Fe}_{2} \mathrm{~S}_{2}(\mathrm{CO})_{6}\right]$ assembly can also be observed to contribute to the charge transfer process.

\section{EXPERIMENTAL SECTION}

All chemicals were obtained from commercial suppliers and used without further purification, unless otherwise noted. Detailed information on instrumentation, materials, and methods is listed in the Supporting Information.

Synthesis. CdSe quantum dots, ${ }^{29}\left[\mathrm{Fe}_{2} \mathrm{~S}_{2}(\mathrm{CO})_{6}\right],{ }^{30} \mathrm{~g}^{-\mathrm{C}_{3} \mathrm{~N}_{4}}$ nanosheets, ${ }^{31,32}$ and CdSe quantum dot $/\left[\mathrm{Fe}_{2} \mathrm{~S}_{2}(\mathrm{CO})_{6}\right]$ assemblies $^{12}$ were synthesized with slight modifications of published methods.

Synthesis of CdSe QDs. The water-soluble CdSe QDs were synthesized according to a slight modification of a literature method (see the Supporting Information). ${ }^{29}$

Synthesis of the CdSe Quantum Dot/[Fe $\left.\mathrm{S}_{2}(\mathrm{CO})_{6}\right]$ Assembly. The water-soluble $\mathrm{CdSe}$ quantum $\operatorname{dot} /\left[\mathrm{Fe}_{2} \mathrm{~S}_{2}(\mathrm{CO})_{6}\right]$ assembly was synthesized according to the method described by $\mathrm{Wu}$ and coworkers. $^{12}\left[\mathrm{Fe}_{2} \mathrm{~S}_{2}(\mathrm{CO})_{6}\right]$, which may be considered to be a molecular mimic of the $[\mathrm{FeFe}]$-hydrogenase active site, was selected as the catalyst to interact with the surface of the CdSe quantum dots. An interface-directed synthetic method was used to construct the assembly. ${ }^{12,13}$ An aqueous solution of CdSe quantum dots $(1.2 \times$ $\left.10^{-4} \mathrm{M}\right)$ was mixed with a dichloromethane solution of $\left[\mathrm{Fe}_{2} \mathrm{~S}_{2}(\mathrm{CO})_{6}\right]$ $\left(1.0 \times 10^{-2} \mathrm{M}\right)$ by stirring for $12 \mathrm{~h}$ at room temperature. The water phase of the mixture was collected, precipitated, and rinsed several times with propanol and water to obtain the assembly.

Preparation of $g-C_{3} N_{4}, g-C_{3} N_{4} / C d S e$ Quantum Dot and $g-C_{3} N_{4} /$ CdSe Quantum Dot/[Fe $\left.\mathrm{S}_{2}(\mathrm{CO})_{6}\right]$ Composites. The g- $\mathrm{C}_{3} \mathrm{~N}_{4}$ nanosheets, g- $\mathrm{C}_{3} \mathrm{~N}_{4} / \mathrm{CdSe}$ quantum dot, and $\mathrm{g}-\mathrm{C}_{3} \mathrm{~N}_{4} / \mathrm{CdSe}$ quantum dot/ 

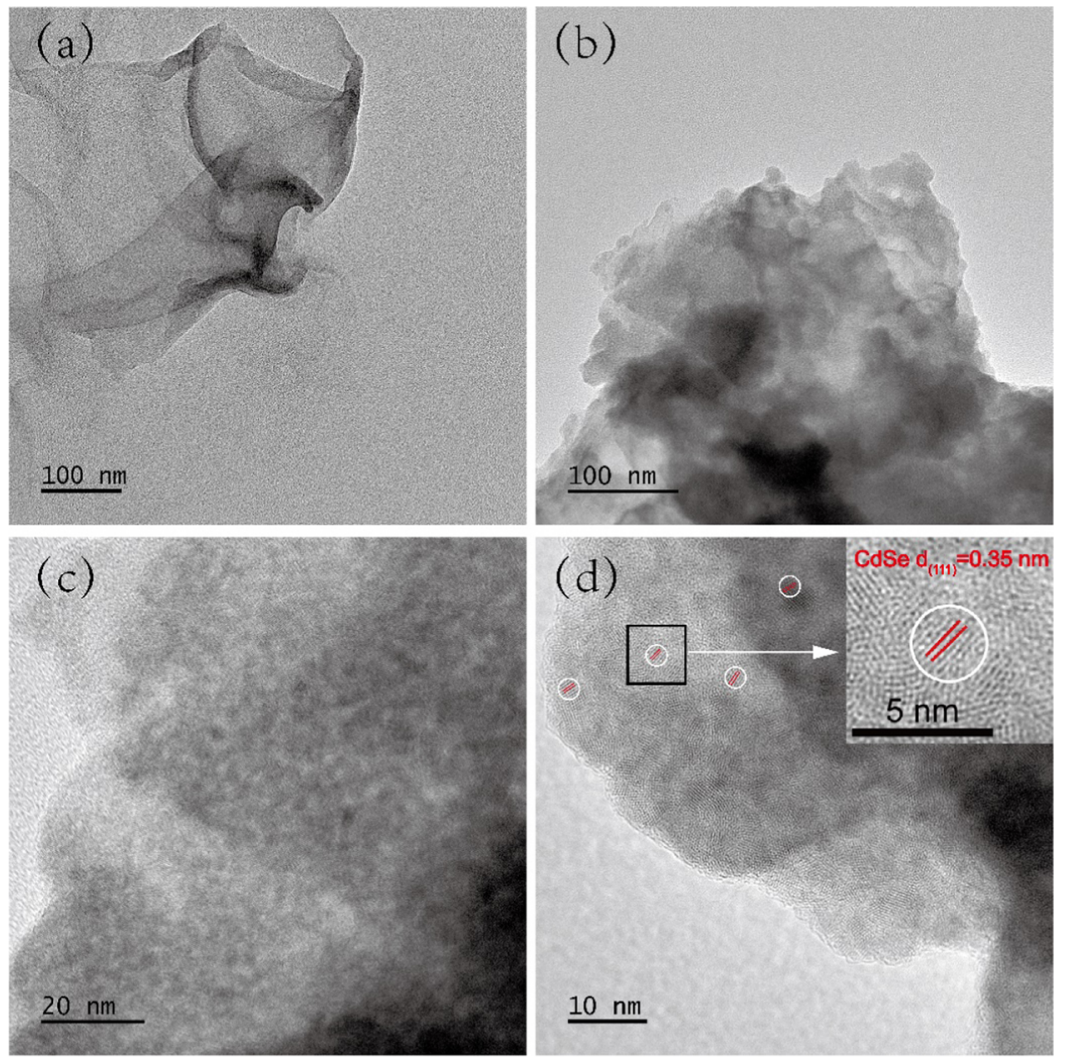

Figure 1. (a) TEM images of pure $g-\mathrm{C}_{3} \mathrm{~N}_{4} ;(\mathrm{b}-\mathrm{d})$ TEM images of the $\mathrm{g}-\mathrm{C}_{3} \mathrm{~N}_{4} / \mathrm{CdSe}$ quantum dot $/\left[\mathrm{Fe}_{2} \mathrm{~S}_{2}(\mathrm{CO})_{6}\right]$ composite.
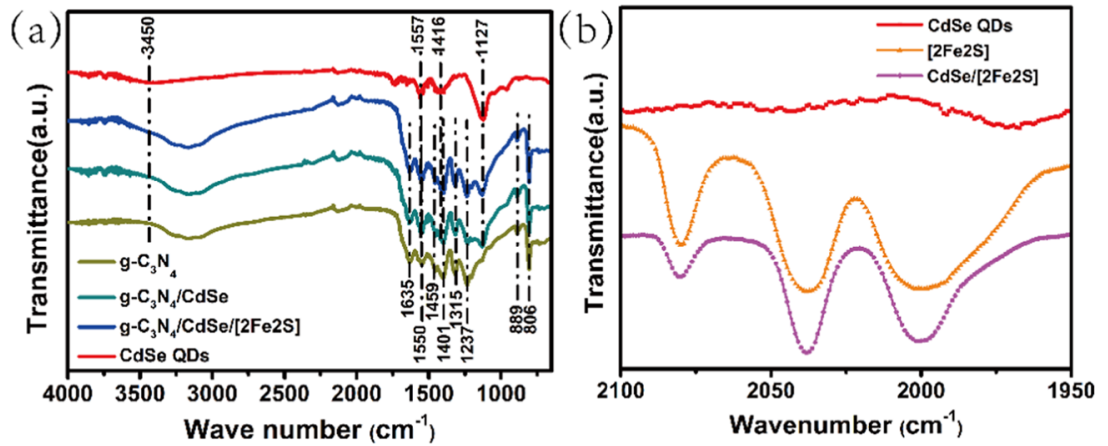

Figure 2. (a) FTIR spectra of g- $\mathrm{C}_{3} \mathrm{~N}_{4}$ (dark yellow trace), CdSe quantum dots (red trace), g- $\mathrm{C}_{3} \mathrm{~N}_{4} / \mathrm{CdSe}$ quantum dot (dark cyan trace), and g$\mathrm{C}_{3} \mathrm{~N}_{4} / \mathrm{CdSe}$ quantum dot/[ $\left.\mathrm{Fe}_{2} \mathrm{~S}_{2}(\mathrm{CO})_{6}\right]$ composite (blue trace) in solid state ( $\mathrm{KBr}$ pellets). (b) Solid-state FTIR spectra of the CdSe quantum dots (red trace), $\left[\mathrm{Fe}_{2} \mathrm{~S}_{2}(\mathrm{CO})_{6}\right]$ (orange trace), and CdSe quantum dots/[ $\left[\mathrm{Fe}_{2} \mathrm{~S}_{2}(\mathrm{CO})_{6}\right]$ assembly (magenta trace) in the $\nu_{\mathrm{C}-\mathrm{O}}$ region. ${ }^{12}$

$\left[\mathrm{Fe}_{2} \mathrm{~S}_{2}(\mathrm{CO})_{6}\right]$ composites were synthesized according to the method described by Zhou and co-workers. ${ }^{28}$ Graphitic carbon nitride (50 $\mathrm{mg}$ ) in $10 \mathrm{~mL}$ of ethanol was subjected to sonication for $1 \mathrm{~h}$. To the resultant solution, $40 \mathrm{~mL}$ of a solution of CdSe quantum dots or CdSe quantum dot $/\left[\mathrm{Fe}_{2} \mathrm{~S}_{2}(\mathrm{CO})_{6}\right]$ assembly $(0.31 \mathrm{mg} / \mathrm{mL})$ and $100 \mu \mathrm{L}$ of 3 -mercaptopropionic acid were added and the resultant mixture was stirred for $2 \mathrm{~h}$. The suspension was centrifuged and dried to obtain samples. Inductively coupled plasma-optical emission spectroscopy (ICP-OES) was used to determine the proportion of CdSe in the g$\mathrm{C}_{3} \mathrm{~N}_{4} / \mathrm{CdSe}$ quantum dot/ $\left[\mathrm{Fe}_{2} \mathrm{~S}_{2}(\mathrm{CO})_{6}\right]$ composite, which was found to be $5 \%(\mathrm{w} / \mathrm{w})$. See the Results and Discussion for the characterization of the composite.

Photocatalysis Experiments. The photocatalytic $\mathrm{H}_{2}$ evolution experiments were performed at room temperature. A total of $2 \mathrm{mg}$ of pure CdSe quantum dots, or $2 \mathrm{mg}$ of the CdSe quantum dot/

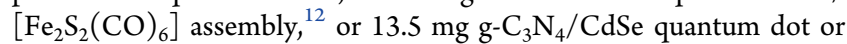
g- $\mathrm{C}_{3} \mathrm{~N}_{4} / \mathrm{CdSe}$ quantum dot/ $\left[\mathrm{Fe}_{2} \mathrm{~S}_{2}(\mathrm{CO})_{6}\right]$ assembly composite (with a CdSe content of $0.675 \mathrm{mg})$, and $200 \mathrm{mg}(0.125 \mathrm{M})$ ascorbic acid
$\left(\mathrm{H}_{2} \mathrm{~A}\right)$, were added into $10 \mathrm{~mL}$ of water in a $50 \mathrm{~mL}$ photocatalysis reactor to construct the $\mathrm{H}_{2}$ evolution systems. The reactions were carried out under irradiation by a $300 \mathrm{~W}$ Xenon lamp. Detection of (the photogenerated) hydrogen gas was made by gas chromatography (GC) analysis using a molecular sieve column (5 ̊), a thermal conductivity detector, and argon carrier gas.

\section{RESULTS AND DISCUSSION}

Sample Characterization. The $\mathrm{g}-\mathrm{C}_{3} \mathrm{~N}_{4} / \mathrm{CdSe}$ quantum dot assemblies and g- $\mathrm{C}_{3} \mathrm{~N}_{4} / \mathrm{CdSe}$ quantum dot/ $\left[\mathrm{Fe}_{2} \mathrm{~S}_{2}(\mathrm{CO})_{6}\right]$ composites were synthesized as depicted schematically in Scheme 1. The graphitic $\mathrm{C}_{3} \mathrm{~N}_{4}$ was found to provide ideal sites for interfacial connection with $\mathrm{CdSe}$ quantum dot/ $\left[\mathrm{Fe}_{2} \mathrm{~S}_{2}(\mathrm{CO})_{6}\right]$ assemblies (vide infra), ${ }^{33}$ resulting in the formation of $\mathrm{g}-\mathrm{C}_{3} \mathrm{~N}_{4} / \mathrm{CdSe}$ quantum dot/[ $\left.\mathrm{Fe}_{2} \mathrm{~S}_{2}(\mathrm{CO})_{6}\right]$ composites. The structures of the composites were identified by transmission electron microscopy (TEM). As shown in 

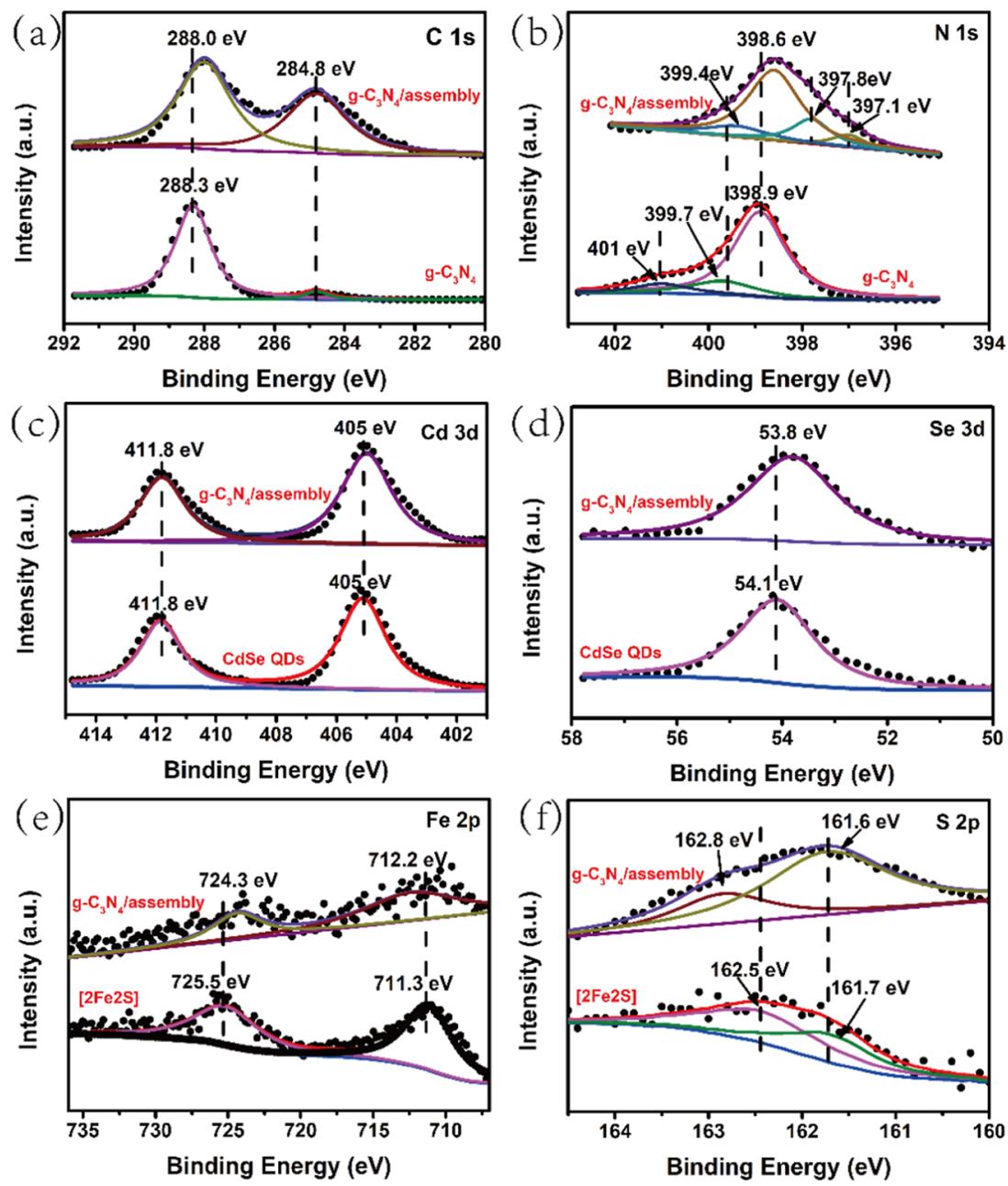

Figure 3. XPS spectra for (a) C 1s, (b) N 1s, (c) Cd 3d, (d) Se 3d, (e) Fe 2p, and (f) S 2p core levels (raw data: dotted line; fitting data: solid line). In all six plots, the traces for the g- $\mathrm{C}_{3} \mathrm{~N}_{4} / \mathrm{CdSe}$ quantum dot $/\left[\mathrm{Fe}_{2} \mathrm{~S}_{2}(\mathrm{CO})_{6}\right]$ composite are plotted as the top trace with that for the pure g$\mathrm{C}_{3} \mathrm{~N}_{4}(\mathrm{a}, \mathrm{b})$; pure quantum dot $(\mathrm{c}, \mathrm{d})(\mathrm{a}, \mathrm{b})$ or pure $\left[\mathrm{Fe}_{2} \mathrm{~S}_{2}(\mathrm{CO})_{6}\right]$ cluster plotted below.

Figure $1 \mathrm{~b}$, a lamellar-like structure of the $\mathrm{g}-\mathrm{C}_{3} \mathrm{~N}_{4} / \mathrm{CdSe}$ quantum dot $/\left[\mathrm{Fe}_{2} \mathrm{~S}_{2}(\mathrm{CO})_{6}\right]$ composite that resembles that of pure $\mathrm{g}-\mathrm{C}_{3} \mathrm{~N}_{4}$ shown in Figure 1a, indicating that the composite is very stable. In Figure $1 \mathrm{c}, \mathrm{d}$, it can be seen that small grains with clear bright and dark stripes of sizes in the range of 2-3 $\mathrm{nm}$ exist in the $\mathrm{g}-\mathrm{C}_{3} \mathrm{~N}_{4} / \mathrm{CdSe}$ quantum dot/ $\left[\mathrm{Fe}_{2} \mathrm{~S}_{2}(\mathrm{CO})_{6}\right]$ composite. The lattice fringes with a d-spacing equal to 0.35 $\mathrm{nm}$ are assigned to the (111) crystal plane of the CdSe quantum dots with a zinc blende structure (Figure 1d). ${ }^{28}$ Energy-dispersive $\mathrm{X}$-ray spectroscopy (EDX) was also used to analyze the $\mathrm{g}-\mathrm{C}_{3} \mathrm{~N}_{4} / \mathrm{CdSe}$ quantum $\mathrm{dot} /\left[\mathrm{Fe}_{2} \mathrm{~S}_{2}(\mathrm{CO})_{6}\right]$ composite (Figure $\mathrm{S} 1$ ). The EDX spectra indicate that the composite mainly contains $\mathrm{C}$ and $\mathrm{N}$, and $\mathrm{Cd}, \mathrm{Se}, \mathrm{Fe}$, and $\mathrm{S}$ evenly distributed on the $\mathrm{g}-\mathrm{C}_{3} \mathrm{~N}_{4}$ sheet (Figure S2). The element proportions that were found by EDX are consistent with the ICP-OES measurements. All observations strongly indicate that the CdSe quantum dot/ $\left[\mathrm{Fe}_{2} \mathrm{~S}_{2}(\mathrm{CO})_{6}\right]$ assembly was successfully adsorbed on the surface of the $\mathrm{g}-\mathrm{C}_{3} \mathrm{~N}_{4}$ sheets.

The Fourier transform infrared (FTIR) spectra of pure g$\mathrm{C}_{3} \mathrm{~N}_{4}$, pure CdSe quantum dots, g- $\mathrm{C}_{3} \mathrm{~N}_{4} / \mathrm{CdSe}$ quantum dot

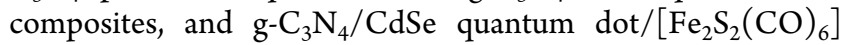
composites were recorded in $\mathrm{KBr}$ pellets and are shown in Figure 2a. Pure $\mathrm{g}-\mathrm{C}_{3} \mathrm{~N}_{4}$ displays three specific absorption regions around 3200-3400, 1200-1700, and $806 \mathrm{~cm}^{-1}$, respectively. ${ }^{27,34}$ The first, broad, resonance at $3200-3400$ $\mathrm{cm}^{-1}$ may be assigned to the stretching mode of the $\mathrm{NH}_{2} / \mathrm{N}-$ $\mathrm{H}$ groups at the surface and edges of the two-dimensional g$\mathrm{C}_{3} \mathrm{~N}_{4}$ sheet. ${ }^{27}$ The resonances in the $1200-1700 \mathrm{~cm}^{-1}$ interval — such as 1635, 1550, 1459, 1401, 1315, and $1237 \mathrm{~cm}^{-1}$ are ascribed to the typical stretching modes of $\mathrm{CN}$ heterocycles. $^{27}$ The resonance at $806 \mathrm{~cm}^{-1}$ belongs to the characteristic breathing mode of the triazine units. ${ }^{34,35}$ For pure CdSe quantum dots, the broad resonance around 3450 $\mathrm{cm}^{-1}$ is attributed to water adsorbed on the surfaces of the quantum dots. ${ }^{28,36}$ The characteristic region around $1557 \mathrm{~cm}^{-1}$ may be attributed to the $\mathrm{C}=\mathrm{O}$ stretching of the mercaptopropionate (MPA) caps on the quantum dots, while the resonance at $1416 \mathrm{~cm}^{-1}$ arises from $\mathrm{CH}_{2}$ scissoring next to $\mathrm{C}=\mathrm{O}$ groups. ${ }^{37}$ The characteristic resonance at 1127 $\mathrm{cm}^{-1}$ may be attributed to the $\mathrm{Cd}-\mathrm{Se}$ bond stretch. ${ }^{37}$ For the g- $\mathrm{C}_{3} \mathrm{~N}_{4} / \mathrm{CdSe}$ and $\mathrm{g}-\mathrm{C}_{3} \mathrm{~N}_{4} / \mathrm{CdSe} /\left[\mathrm{Fe}_{2} \mathrm{~S}_{2}(\mathrm{CO})_{6}\right]$ assemblies, the IR spectra characteristic of $\mathrm{g}-\mathrm{C}_{3} \mathrm{~N}_{4}$ and $\mathrm{CdSe}$ may also be identified, confirming that the composite contains both $\mathrm{g}-\mathrm{C}_{3} \mathrm{~N}_{4}$ and $\mathrm{CdSe}$. While the $\mathrm{C}-\mathrm{O}$ stretches of the iron carbonyl dimers can be identified in the vibration spectra of CdSe quantum dot $/\left[\mathrm{Fe}_{2} \mathrm{~S}_{2}(\mathrm{CO})_{6}\right]$ assemblies ${ }^{12,13}$ (Figure $2 \mathrm{~b}$ ), the iron clusters are too disperse to be detected in the corresponding $\mathrm{g}-\mathrm{C}_{3} \mathrm{~N}_{4}$ composites where the resonances due to the carbon nitride dominate (Figure 2a). Figure S3 shows the powder X-ray diffraction (XRD) patterns of pure $\mathrm{g}-\mathrm{C}_{3} \mathrm{~N}_{4}$, 

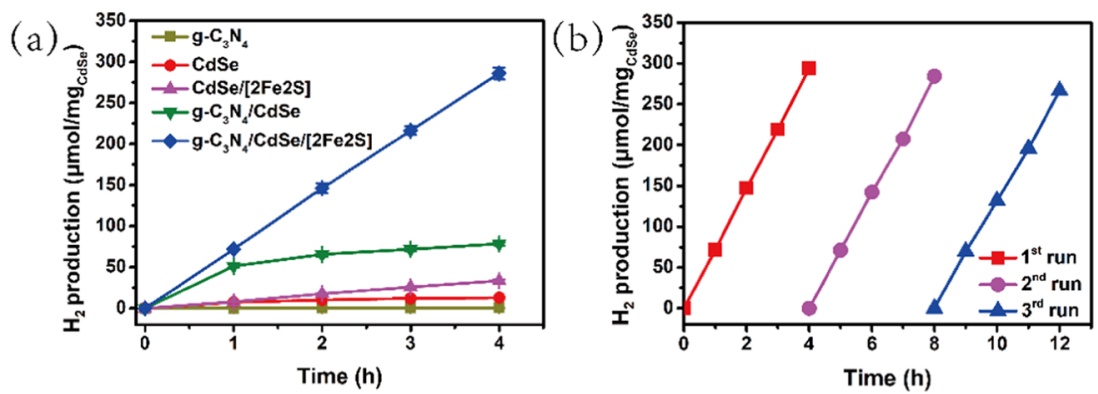

Figure 4. (a) Photocatalytic $\mathrm{H}_{2}$ evolution over different photocatalysts under light irradiation $\mathrm{g}-\mathrm{C}_{3} \mathrm{~N}_{4}$ (dark yellow trace), CdSe quantum dots (red trace), CdSe quantum dot/[2Fe2S] assembly (magenta trace), and g- $\mathrm{C}_{3} \mathrm{~N}_{4} / \mathrm{CdSe}$ quantum dot $/\left[\mathrm{Fe}_{2} \mathrm{~S}_{2}(\mathrm{CO})_{6}\right]$ composite (blue trace). (b) $\mathrm{H}_{2}$ production in three repeated cycles utilizing the $\mathrm{g}-\mathrm{C}_{3} \mathrm{~N}_{4} / \mathrm{CdSe} /\left[\mathrm{Fe}_{2} \mathrm{~S}_{2}(\mathrm{CO})_{6}\right]$ composite as a photocatalyst. Error bars represent mean standard deviations from three independent experiments.

the $\mathrm{g}-\mathrm{C}_{3} \mathrm{~N}_{4} / \mathrm{CdSe}$, the $\mathrm{g}-\mathrm{C}_{3} \mathrm{~N}_{4} / \mathrm{CdSe} /\left[\mathrm{Fe}_{2} \mathrm{~S}_{2}(\mathrm{CO})_{6}\right]$ composite and pure $\mathrm{CdSe}$ quantum dots. The XRD pattern of $\mathrm{CdSe}$ exhibits three peaks at $26.6,42.6$, and $50.3^{\circ}$ that are ascribed to diffractions from the (111), (220), and (311) planes, respectively, corresponding to the face-centered cubic (zinc blende) crystalline structure of $\mathrm{CdSe}{ }^{28,38}$ The g- $\mathrm{C}_{3} \mathrm{~N}_{4}$ sample has two distinct peaks at 13.1 and $27.4^{\circ}$, in agreement with literature results. ${ }^{39}$ It may be noticed that a weak intensity at $26.6^{\circ}$ due to CdSe is found in the g- $\mathrm{C}_{3} \mathrm{~N}_{4} / \mathrm{CdSe}$ and $\mathrm{g}-\mathrm{C}_{3} \mathrm{~N}_{4} /$ $\mathrm{CdSe} /\left[\mathrm{Fe}_{2} \mathrm{~S}_{2}(\mathrm{CO})_{6}\right]$ composite, but the peak of $\mathrm{g}-\mathrm{C}_{3} \mathrm{~N}_{4}$ at $13.1^{\circ}$ cannot be observed due to its weak intensity (Figure S3). Based on the powder XRD results, it may be concluded that a g- $\mathrm{C}_{3} \mathrm{~N}_{4} / \mathrm{CdSe}$ composite with $\mathrm{g}-\mathrm{C}_{3} \mathrm{~N}_{4}$ and $\mathrm{CdSe}$ phases is formed.

The Brunauer-Emmett-Teller (BET) surface areas and porosities of pure g- $\mathrm{C}_{3} \mathrm{~N}_{4}$ and the g- $\mathrm{C}_{3} \mathrm{~N}_{4} / \mathrm{CdSe}$ quantum dot/ $\left[\mathrm{Fe}_{2} \mathrm{~S}_{2}(\mathrm{CO})_{6}\right]$ composite were investigated by $\mathrm{N}_{2}$ adsorption measurements at room temperature (Figure S4). The BET surface of $\mathrm{g}-\mathrm{C}_{3} \mathrm{~N}_{4}$ and the $\mathrm{g}-\mathrm{C}_{3} \mathrm{~N}_{4} / \mathrm{CdSe}$ quantum dot/ $\left[\mathrm{Fe}_{2} \mathrm{~S}_{2}(\mathrm{CO})_{6}\right]$ composite are 14.53 and $15.26 \mathrm{~m}^{2} / \mathrm{g}$, respectively, indicating that adhesion of the assembly does not alter the porous properties of $\mathrm{g}-\mathrm{C}_{3} \mathrm{~N}_{4}$. X-ray photoelectron spectroscopy (XPS) was employed to investigate the surface compositions and chemical states of all related samples. As shown in Figure S5, the full XPS spectrum of the pure g- $\mathrm{C}_{3} \mathrm{~N}_{4}$ verified the existence of the chemical elements carbon and nitrogen. The $\mathrm{g}-\mathrm{C}_{3} \mathrm{~N}_{4} / \mathrm{CdSe}$ quantum dot $/\left[\mathrm{Fe}_{2} \mathrm{~S}_{2}(\mathrm{CO})_{6}\right]$ composite shows $\mathrm{Cd} 3 \mathrm{~d}$, Se $3 \mathrm{~d}, \mathrm{Fe} 2 \mathrm{p}$, and $\mathrm{S} 2 \mathrm{p}$ peaks, indicating successful grafting of both the CdSe quantum dots and $\left[\mathrm{Fe}_{2} \mathrm{~S}_{2}(\mathrm{CO})_{6}\right]$ or the quantum dot/cluster assembly onto the $\mathrm{g}-\mathrm{C}_{3} \mathrm{~N}_{4}$ sheet. The $\mathrm{C} 1 \mathrm{~s}$ spectrum of pure $\mathrm{g}-\mathrm{C}_{3} \mathrm{~N}_{4}$ shown in Figure 3a reveals two peaks at 284.8 and $288.3 \mathrm{eV}$. The two carbon peaks are ascribed to $\mathrm{sp}^{2}$-hybridized carbon in $\mathrm{C}-\mathrm{C}$ bonds and the $\mathrm{N}$-containing aromatic rings $(\mathrm{N}-\mathrm{C}=\mathrm{N})$, respectively. ${ }^{23,28}$ Regarding the g- $\mathrm{C}_{3} \mathrm{~N}_{4} / \mathrm{CdSe}$ quantum dot/ $\left[\mathrm{Fe}_{2} \mathrm{~S}_{2}(\mathrm{CO})_{6}\right]$ composite (Figure 3a,b), $\mathrm{C}$ 1s peaks are found at 284.8 and $288.0 \mathrm{eV}$ and are much more dominant compared with those of pure $\mathrm{g}^{-} \mathrm{C}_{3} \mathrm{~N}_{4}$; this may be ascribed to the electron-withdrawing effect of the $\mathrm{CdSe} /\left[\mathrm{Fe}_{2} \mathrm{~S}_{2}(\mathrm{CO})_{6}\right]$ assemblies on $\mathrm{g}-\mathrm{C}_{3} \mathrm{~N}_{4}$. This effect may also contribute to the change of the $\mathrm{N} 1 \mathrm{~s}$ energy in the $\mathrm{g}-\mathrm{C}_{3} \mathrm{~N}_{4} / \mathrm{CdSe} /\left[\mathrm{Fe}_{2} \mathrm{~S}_{2}(\mathrm{CO})_{6}\right]$ composite. The binding energies of the $\mathrm{N} 1 \mathrm{~s}$ spectrum of pure $\mathrm{g}_{-} \mathrm{C}_{3} \mathrm{~N}_{4}$ shown in Figure $3 \mathrm{~b}$ can be deconvoluted into peaks at 398.9, 399.7, and $401 \mathrm{eV}$. The primary peak located at 398.9 $\mathrm{eV}$ can be identified as the $\mathrm{sp}^{2}$-hybridized $\mathrm{N}$ involved in the triazine rings $(\mathrm{C}-\mathrm{N}=\mathrm{C})$, while the other two weak peaks located at 399.6 and $401 \mathrm{eV}$ are assigned to the tertiary nitrogen $\mathrm{N}-(\mathrm{C})_{3}$ groups and charging effects. ${ }^{23,28,40}$ The corresponding binding energies of the $\mathrm{N} 1 \mathrm{~s}$ spectrum of the $\mathrm{g}$ $\mathrm{C}_{3} \mathrm{~N}_{4} / \mathrm{CdSe}$ quantum dot/[ $\left[\mathrm{Fe}_{2} \mathrm{~S}_{2}(\mathrm{CO})_{6}\right]$ composite are determined to be 398.6 and 399.4 (Figure $3 \mathrm{~b}$ ), which can be identified as the $\mathrm{sp}^{2}$-hybridized $\mathrm{N}$ involved in the triazine rings and the tertiary nitrogen $\mathrm{N}-(\mathrm{C})_{3}$ groups, respectively. The new binding energies for $\mathrm{N} 1 \mathrm{~s}$ at 397.1 and $397.8 \mathrm{eV}$ may be attributed to the existence of metal-nitrogen bond $(\mathrm{s}) .{ }^{33}$ The XPS spectrum of $\mathrm{Cd} 3 \mathrm{~d}$ both in pure CdSe quantum dots and

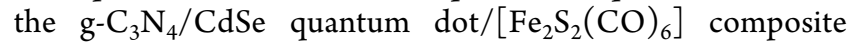
reveals peaks at 405 and $411.8 \mathrm{eV}$ that are assigned to the binding energies of $\mathrm{Cd} 3 \mathrm{~d}_{5 / 2}$ and $\mathrm{Cd} 3 \mathrm{~d}_{3 / 2}$ (Figure $3 \mathrm{c}$ ). Figure $3 \mathrm{~d}$ shows similar XPS peaks for Se at 54.1 and $53.8 \mathrm{eV}$ in pure CdSe QDs and the g- $\mathrm{C}_{3} \mathrm{~N}_{4} / \mathrm{CdSe} /\left[\mathrm{Fe}_{2} \mathrm{~S}_{2}(\mathrm{CO})_{6}\right]$ composite, respectively; these peaks are attributed to $\mathrm{Se} 3 \mathrm{~d}$ energies. The XPS spectrum for $\mathrm{Fe} 2 \mathrm{p}$ may be fitted by two peaks at 711.3 $\mathrm{eV}, 725.5 \mathrm{eV}$ for pure $\left[\mathrm{Fe}_{2} \mathrm{~S}_{2}(\mathrm{CO})_{6}\right]$, and $712.2 \mathrm{eV}, 724.3 \mathrm{eV}$ for the $\mathrm{g}-\mathrm{C}_{3} \mathrm{~N}_{4} / \mathrm{CdSe}$ quantum $\mathrm{dot} /\left[\mathrm{Fe}_{2} \mathrm{~S}_{2}(\mathrm{CO})_{6}\right]$ composite, respectively (Figure $3 \mathrm{e}$ ), and are assigned to the binding energies of $\mathrm{Fe} 2 \mathrm{p}_{1 / 2}$ and $\mathrm{Fe} 2 \mathrm{p}_{3 / 2}$. The XPS spectrum of $\mathrm{S} 2 \mathrm{p}$ is also devolved into two peaks at $161.7 \mathrm{eV}, 162.5 \mathrm{eV}$ in pure $\left[\mathrm{Fe}_{2} \mathrm{~S}_{2}(\mathrm{CO})_{6}\right]$ and $161.6 \mathrm{eV}, 162.8 \mathrm{eV}$ in the $\mathrm{g}-\mathrm{C}_{3} \mathrm{~N}_{4} / \mathrm{CdSe}$ quantum dot $/\left[\mathrm{Fe}_{2} \mathrm{~S}_{2}(\mathrm{CO})_{6}\right]$ composite, respectively (Figure 3f), and may be assigned to the binding energies of $S 2 p_{3 / 2}$ and $\mathrm{S} 2 \mathrm{p}_{1 / 2}$. The shift of $\mathrm{Fe} 2 \mathrm{p}$ core level to the lower binding energy in the composite sample also indicates a change in the coordination around $\mathrm{Fe}$ atoms. These results indicate strong interaction resulting in overlap of charge-transfer states or electron wavefunctions between the $\mathrm{CdSe} /\left[\mathrm{Fe}_{2} \mathrm{~S}_{2}(\mathrm{CO})_{6}\right]$ assembly and $\mathrm{g}-\mathrm{C}_{3} \mathrm{~N}_{4}$.

Photocatalytic $\mathrm{H}_{2}$ Evolution Activity. In the photocatalytic $\mathrm{H}_{2}$ production experiments, the g- $\mathrm{C}_{3} \mathrm{~N}_{4} / \mathrm{CdSe} /$ $\left[\mathrm{Fe}_{2} \mathrm{~S}_{2}(\mathrm{CO})_{6}\right]$ composite showed significantly enhanced activity for hydrogen evolution relative to the related catalytic systems (Figure 4a). For systematic comparison, all of the systems were kept at the same concentration of CdSe quantum dots and sacrificial electron donor $\mathrm{H}_{2} \mathrm{~A}$ (ascorbic acid, 0.125 $\mathrm{M})$ at $\mathrm{pH} 4.0$, conditions relevant to previous related studies. ${ }^{13}$ Under visible light irradiation for $4 \mathrm{~h}$, the total amount of $\mathrm{H}_{2}$ production by the $\mathrm{g}-\mathrm{C}_{3} \mathrm{~N}_{4} / \mathrm{CdSe}$ quantum dot $/\left[\mathrm{Fe}_{2} \mathrm{~S}_{2}(\mathrm{CO})_{6}\right]$ composite was $286 \mu \mathrm{mol} / \mathrm{mg}$ (based on CdSe quantum dots), about 9 times as high as the $\mathrm{CdSe} /\left[\mathrm{Fe}_{2} \mathrm{~S}_{2}(\mathrm{CO})_{6}\right]$ assembly in the absence of $\mathrm{g}-\mathrm{C}_{3} \mathrm{~N}_{4}$, and significantly higher than either the $\mathrm{CdSe}$ quantum dots or $\mathrm{g}-\mathrm{C}_{3} \mathrm{~N}_{4}$ alone (Figure 4a). To evaluate the stability, recycling of the $\mathrm{g}-\mathrm{C}_{3} \mathrm{~N}_{4} / \mathrm{CdSe} /\left[\mathrm{Fe}_{2} \mathrm{~S}_{2}(\mathrm{CO})_{6}\right]$ composites, as well as a more long-term hydrogen production experiment with the composite, have been studied under the 

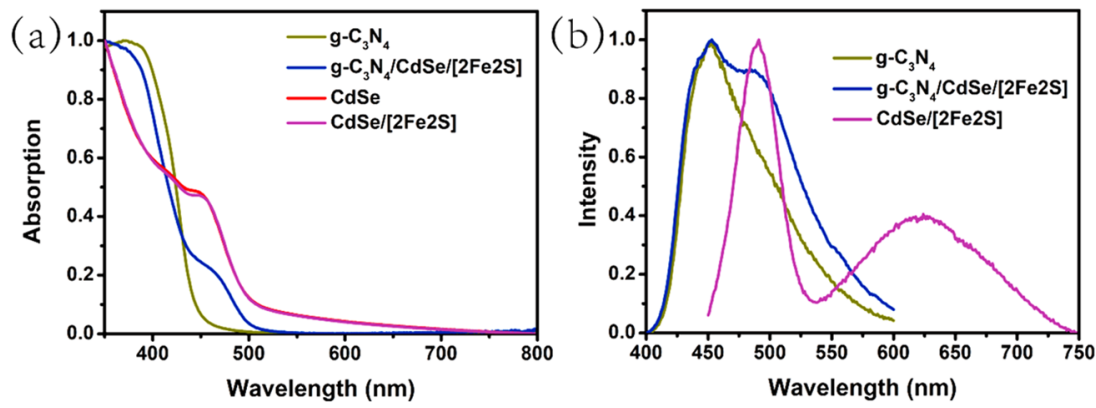

Figure 5. (a) UV-vis spectra of different photocatalysts. (b) Steady-state photoluminescence spectra of different photocatalysts (excitation at 350 $\mathrm{nm}$ ), g- $\mathrm{C}_{3} \mathrm{~N}_{4}$ (dark yellow trace), CdSe quantum dots (red trace), CdSe quantum dot/[2Fe2S] assembly (magenta trace), and g-C $\mathrm{N}_{4} / \mathrm{CdSe}$ quantum dot $/\left[\mathrm{Fe}_{2} \mathrm{~S}_{2}(\mathrm{CO})_{6}\right]$ composite (blue trace).

same conditions as the initial $4 \mathrm{~h}$ experiments (Figures S6 and $4 \mathrm{~b})$. The total amount of hydrogen production under $12 \mathrm{~h}$ light irradiation by the $\mathrm{g}-\mathrm{C}_{3} \mathrm{~N}_{4} / \mathrm{CdSe}$ quantum dot/ $\left[\mathrm{Fe}_{2} \mathrm{~S}_{2}(\mathrm{CO})_{6}\right]$ composite was found to be $790 \mu \mathrm{mol} / \mathrm{mg}$ (based on CdSe quantum dots). The hydrogen production rate of the $\mathrm{g}-\mathrm{C}_{3} \mathrm{~N}_{4} / \mathrm{CdSe}$ quantum dot/ $\left[\mathrm{Fe}_{2} \mathrm{~S}_{2}(\mathrm{CO})_{6}\right]$ composite during the $12 \mathrm{~h}$ reaction is around $66 \mu \mathrm{mol} / \mathrm{mg} / \mathrm{h}$, while the 4 $\mathrm{h}$ (or first $4 \mathrm{~h}$ ) reaction is $71.5 \mu \mathrm{mol} / \mathrm{mg} / \mathrm{h}$. The consumption of the sacrificial agent over time results in a gradual lowering of the effective concentration of ascorbate and a slightly lower hydrogen production rate in the long-term hydrogen production. For the recycling experiments, the $\mathrm{H}_{2}$ production remained stable in each cycle and the $\mathrm{H}_{2}$ production efficiency remained better than $90 \%$ after three cycles. Pure CdSe quantum dots would be expected to aggregate and become unstable under continuous recycling ${ }^{16,17}$ due to their small size and photocorrosion, resulting in reduced photocatalytic activity.

To assess the integrity of the composites/catalysts after the reaction, the composites were studied by XPS (Figure S5) and TEM (Figure S7) after completing hydrogen evolution runs. It was found that the CdSe quantum $\mathrm{dot} /[2 \mathrm{Fe} 2 \mathrm{~S}]$ assembly remained intact on the $\mathrm{g}-\mathrm{C}_{3} \mathrm{~N}_{4}$ sheet after the photocatalytic reactions, with characteristic XPS peaks and lattice structure as revealed by TEM. Both the long-term reaction and the recycling experiments illustrate the excellent stability of the g$\mathrm{C}_{3} \mathrm{~N}_{4} / \mathrm{CdSe}$ quantum dot/ $\left[\mathrm{Fe}_{2} \mathrm{~S}_{2}(\mathrm{CO})_{6}\right]$ composite in photocatalytic hydrogen reactions.

Optical Characterization. The optical absorption behaviors of the g- $\mathrm{C}_{3} \mathrm{~N}_{4}$, g- $\mathrm{C}_{3} \mathrm{~N}_{4} / \mathrm{CdSe}$ quantum dots, g- $\mathrm{C}_{3} \mathrm{~N}_{4} / \mathrm{CdSe}$ quantum dot/ $\left[\mathrm{Fe}_{2} \mathrm{~S}_{2}(\mathrm{CO})_{6}\right]$ composite, $\mathrm{CdSe}$ quantum dots, and the $\mathrm{CdSe}$ quantum $\mathrm{dot} /\left[\mathrm{Fe}_{2} \mathrm{~S}_{2}(\mathrm{CO})_{6}\right]$ assembly were studied using UV-vis spectroscopy. As shown in Figure 5a, g$\mathrm{C}_{3} \mathrm{~N}_{4}$ by itself shows a fundamental absorption edge located at approximately $460 \mathrm{~nm}$ that is a result of its intrinsic band gap of $2.7 \mathrm{eV}^{41}$ Pristine $\mathrm{CdSe}$ quantum dots as wells as the quantum dot $/\left[\mathrm{Fe}_{2} \mathrm{~S}_{2}(\mathrm{CO})_{6}\right]$ assembly show the typical ${ }^{1} \mathrm{~S}$ exciton band at around $449 \mathrm{~nm}$ displayed in Figure 5a, which corresponds to an optical band gap of $2.76 \mathrm{eV} .^{13}$ The heterostructures of the $\mathrm{g}-\mathrm{C}_{3} \mathrm{~N}_{4} / \mathrm{CdSe}$ quantum dot and $\mathrm{g}$ $\mathrm{C}_{3} \mathrm{~N}_{4} / \mathrm{CdSe}$ quantum dot/[$\left[\mathrm{Fe}_{2} \mathrm{~S}_{2}(\mathrm{CO})_{6}\right]$ composites both show characteristic absorption peaks of pure $\mathrm{g}-\mathrm{C}_{3} \mathrm{~N}_{4}$ and $\mathrm{CdSe}$ quantum dots, which suggest successful integration of the CdSe quantum dots with the $\mathrm{g}-\mathrm{C}_{3} \mathrm{~N}_{4}$ sheet. As shown in Figures $5 \mathrm{~b}$ and $\mathrm{S} 8$, the photoluminescence emission peak is generated from intrinsic band edge emission around $450 \mathrm{~nm}$ for $\mathrm{g}-\mathrm{C}_{3} \mathrm{~N}_{4}$, while the peaks at 500 and $625 \mathrm{~nm}$ for the pure $\mathrm{CdSe}$ quantum dot under excitation at $350 \mathrm{~nm}$, represent the band edge emission and defect emission, respectively. ${ }^{42}$ The g$\mathrm{C}_{3} \mathrm{~N}_{4} / \mathrm{CdSe}$ quantum dot/ $\left[\mathrm{Fe}_{2} \mathrm{~S}_{2}(\mathrm{CO})_{6}\right]$ composite shows peaks around 450 and $500 \mathrm{~nm}$ corresponding to $\mathrm{g}-\mathrm{C}_{3} \mathrm{~N}_{4}$ and $\mathrm{CdSe}$ quantum dots.

Investigation of the Photophysical Process for Photocatalytic $\mathrm{H}_{2}$ Evolution. Efficient charge transfer between the $\mathrm{g}-\mathrm{C}_{3} \mathrm{~N}_{4}$ and photoexcited CdSe quantum dot/ $\left[\mathrm{Fe}_{2} \mathrm{~S}_{2}(\mathrm{CO})_{6}\right]$ assembly is expected because of their intimate contact in the hybrid heterostructure. To confirm this assumption, the energy alignment of the $\mathrm{g}-\mathrm{C}_{3} \mathrm{~N}_{4} / \mathrm{CdSe}$ quantum dot/[$\left[\mathrm{Fe}_{2} \mathrm{~S}_{2}(\mathrm{CO})_{6}\right]$ composite system was first investigated by computational methods. The different energy level positions and energy gaps of the three components have been discussed in a number of previous studies. ${ }^{12,13,43-46}$ The calculated energy levels indicate that for photogenerated hole transfer from $\mathrm{CdSe}$ quantum dots to $\mathrm{g}-\mathrm{C}_{3} \mathrm{~N}_{4}$ or the iron carbonyl cluster is thermodynamically favored in the $\mathrm{g}-\mathrm{C}_{3} \mathrm{~N}_{4} /$ $\mathrm{CdSe}$ quantum dot/ $\left[\mathrm{Fe}_{2} \mathrm{~S}_{2}(\mathrm{CO})_{6}\right]$ composite system (Figure $6)$. The related potentials vs the normal hydrogen electrode

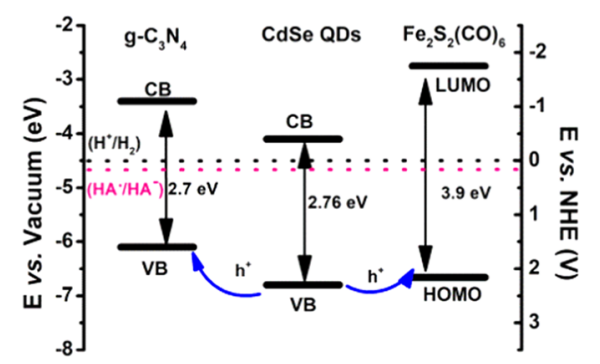

Figure 6. Calculated molecular orbital/band energies (vs vacuum) and schematic charge transfer processes in the $\mathrm{g}-\mathrm{C}_{3} \mathrm{~N}_{4} / \mathrm{CdSe}$ / $\left[\mathrm{Fe}_{2} \mathrm{~S}_{2}(\mathrm{CO})_{6}\right]$ composite. $\mathrm{g}-\mathrm{C}_{3} \mathrm{~N}_{4}$ valence band (highest occupied molecular orbital - HOMO), $-6.1 \mathrm{eV}$; conduction band (lowest unoccupied molecular orbital - LUMO), $-3.4 \mathrm{eV}^{43-45} \mathrm{CdSe}$ quantum dot valence band, $-6.8 \mathrm{eV}$; conduction band, -4.1 $\mathrm{eV}^{12,13,46}\left[\mathrm{Fe}_{2} \mathrm{~S}_{2}(\mathrm{CO})_{6}\right]$ HOMO, $-6.66 \mathrm{eV}$; LUMO, $-2.75 \mathrm{eV}^{13}$

(NHE) at $\mathrm{pH}=4.0$ are also shown in Figure $6 .{ }^{47,48}$ As we have previously emphasized, ${ }^{13}$ there is an inherent uncertainty in the positioning of the absolute energies for the different components in the heterostructured composite, but our spectroscopic results (vide infra) support the qualitative ordering that is depicted in Figure 6.

The photogenerated charge transfer process in the $\mathrm{g}-\mathrm{C}_{3} \mathrm{~N}_{4} /$ $\mathrm{CdSe}$ quantum dot/[$\left[\mathrm{Fe}_{2} \mathrm{~S}_{2}(\mathrm{CO})_{6}\right]$ composite system was investigated by combined transient absorption and timeresolved photoluminescence experiments (Figures $7 \mathrm{a}-\mathrm{d}$ and S9). The typical transient absorption spectra of three different 

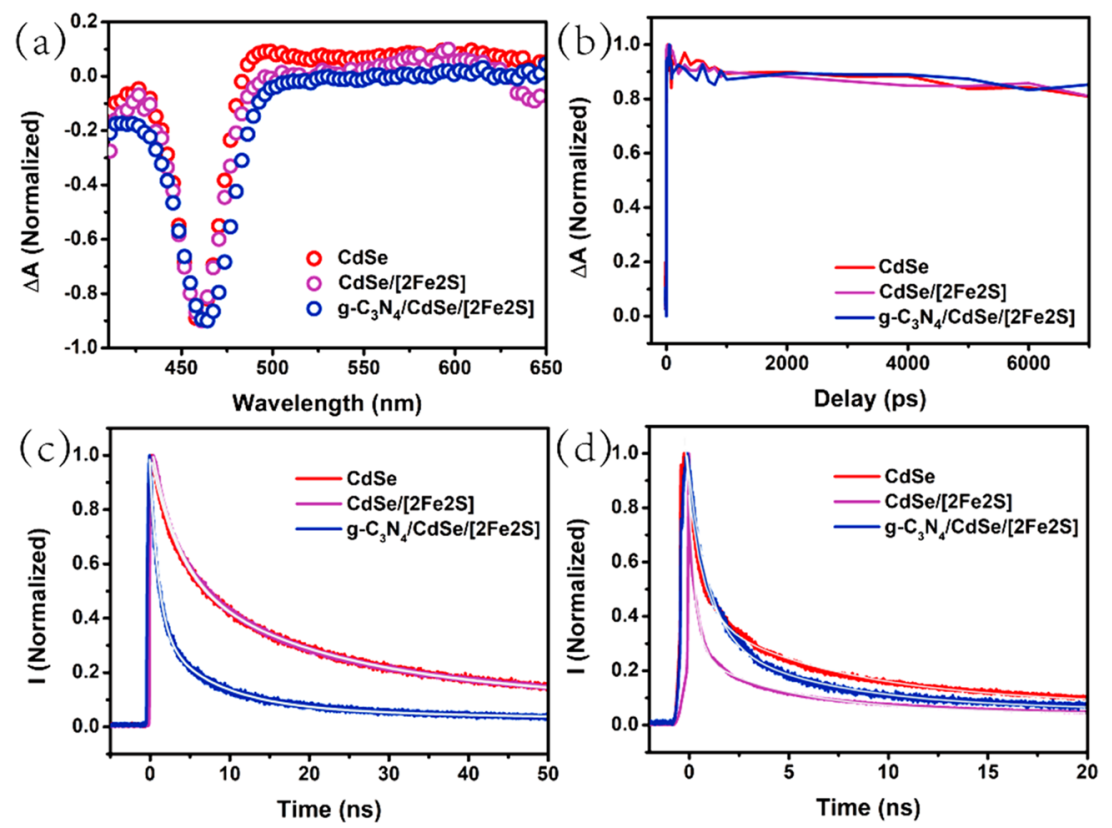

Figure 7. (a) Transient absorption spectra at $10 \mathrm{ps}$ after excitation pump at $400 \mathrm{~nm}, 2 \times 10^{13} \mathrm{ph} / \mathrm{cm}^{2}$. (b) Transient absorption kinetics at the minimum bleach. Pure CdSe quantum dot (red trace), CdSe quantum dots $/\left[\mathrm{Fe}_{2} \mathrm{~S}_{2}(\mathrm{CO})_{6}\right]$ assembly (magenta trace), and g- $\mathrm{C}_{3} \mathrm{~N}_{4} / \mathrm{CdSe}$ quantum dots $/\left[\mathrm{Fe}_{2} \mathrm{~S}_{2}(\mathrm{CO})_{6}\right]$ composite (blue trace). (c) Time-resolved photoluminescence decay $(\lambda>610 \mathrm{~nm}$ ) of pure CdSe quantum dot (red trace), CdSe quantum dots $/\left[\mathrm{Fe}_{2} \mathrm{~S}_{2}(\mathrm{CO})_{6}\right]$ assembly (magenta trace), and $\mathrm{g}-\mathrm{C}_{3} \mathrm{~N}_{4} / \mathrm{CdSe}$ quantum dots $/\left[\mathrm{Fe}_{2} \mathrm{~S}_{2}(\mathrm{CO})_{6}\right]$ composite (blue trace). (d) Timeresolved photoluminescence decay $\left(470 \mathrm{~nm}<\lambda<600 \mathrm{~nm}\right.$ ) of pure CdSe quantum dot (red trace), CdSe quantum dots/[Fe $\left.\mathrm{S}_{2}(\mathrm{CO})_{6}\right]$ assembly (magenta trace), and $\mathrm{g}-\mathrm{C}_{3} \mathrm{~N}_{4} / \mathrm{CdSe}$ quantum dots/[$\left[\mathrm{Fe}_{2} \mathrm{~S}_{2}(\mathrm{CO})_{6}\right]$ composite (blue trace).

samples, namely, pure CdSe quantum dots, the CdSe quantum $\mathrm{dot} /\left[\mathrm{Fe}_{2} \mathrm{~S}_{2}(\mathrm{CO})_{6}\right]$ assembly, and the $\mathrm{g}-\mathrm{C}_{3} \mathrm{~N}_{4} / \mathrm{CdSe}$ quantum $\operatorname{dot} /\left[\mathrm{Fe}_{2} \mathrm{~S}_{2}(\mathrm{CO})_{6}\right]$ composite, are shown in Figure $7 \mathrm{a}$. Similar ground-state bleach (GSB) bands of the three samples are due to population of the band edge state of the quantum dots after excitation. We have previously reported that different kinetics of the CdSe quantum dot ground-state bleach recovery rate can be observed when the quantum dots interact with electron or hole acceptors - a higher GSB recovery rate is observed for electron acceptors while the rate remains the same for hole acceptors. ${ }^{13,49,50}$ The kinetics at the maximum bleach stay almost constant among the pure $\mathrm{CdSe}$ quantum dots, the $\mathrm{CdSe} /\left[\mathrm{Fe}_{2} \mathrm{~S}_{2}(\mathrm{CO})_{6}\right]$ assembly, and the $\mathrm{g}-\mathrm{C}_{3} \mathrm{~N}_{4} / \mathrm{CdSe}$ quantum dot $/\left[\mathrm{Fe}_{2} \mathrm{~S}_{2}(\mathrm{CO})_{6}\right]$ composite, which indicates that no additional depopulation pathway for the excited electrons from the CdSe quantum dots is established in the assembly or composite (Figure $7 \mathrm{~b}$ ).

At the same, different photoluminescence decays of pure CdSe quantum dots, the $\mathrm{CdSe} /\left[\mathrm{Fe}_{2} \mathrm{~S}_{2}(\mathrm{CO})_{6}\right]$ assembly, and the $\mathrm{g}-\mathrm{C}_{3} \mathrm{~N}_{4} / \mathrm{CdSe}$ quantum dot $/\left[\mathrm{Fe}_{2} \mathrm{~S}_{2}(\mathrm{CO})_{6}\right]$ composite can be observed via time-resolved photoluminescence measurements. As the excitation density per quantum dot $\langle N\rangle$ in our experiment is much less than 1 , any possible high-order recombination process (e.g., Auger recombination) may be excluded. As shown in Figure S9, the photoluminescence decay of the pure $\mathrm{CdSe}$ quantum dots is slower than that of the CdSe quantum dot $/\left[\mathrm{Fe}_{2} \mathrm{~S}_{2}(\mathrm{CO})_{6}\right]$ assembly, which indicates that there are more nonradiative recombination pathways in the CdSe quantum dot/ $\left[\mathrm{Fe}_{2} \mathrm{~S}_{2}(\mathrm{CO})_{6}\right]$ assembly. Consistent with our previous study and the calculated/measured relative energies (Figure 6), ${ }^{13}$ hole transfer from the excited state of the $\mathrm{CdSe}$ quantum dots to the $\left[\mathrm{Fe}_{2} \mathrm{~S}_{2}(\mathrm{CO})_{6}\right]$ accounts for the more rapid photoluminescence decay in the composite compared with pure $\mathrm{CdSe}$ quantum dots.
When $\mathrm{g}-\mathrm{C}_{3} \mathrm{~N}_{4}$ is added to the system as a support/matrix, the $\mathrm{g}-\mathrm{C}_{3} \mathrm{~N}_{4} / \mathrm{CdSe}$ quantum $\mathrm{dot} /\left[\mathrm{Fe}_{2} \mathrm{~S}_{2}(\mathrm{CO})_{6}\right]$ composite displays a faster photoluminescence decay than the CdSe quantum dot/ $\left[\mathrm{Fe}_{2} \mathrm{~S}_{2}(\mathrm{CO})_{6}\right]$ assembly (Figure S9). To obtain a better understanding of the photoluminescence kinetics, we distinguished the photoluminescence decays from the defect emission (Figure 7c) and the intrinsic band edge emission (Figure $7 \mathrm{~d}$ ) of CdSe quantum dots at different wavelength regions. The kinetics of the defect emission $(\lambda>610 \mathrm{~nm})$ in Figure $7 \mathrm{c}$ can be fitted biexponentially with time constants $\tau_{1}=$ $7.06 \pm 0.01 \mathrm{~ns}(67 \%)$ and $\tau_{2}=59.82 \pm 0.14 \mathrm{~ns}(33 \%)$ for the pure CdSe quantum dots and $\tau_{1}=7.03 \pm 0.01 \mathrm{~ns}(69 \%)$ and $\tau_{2}$ $=60.30 \pm 0.15 \mathrm{~ns}(31 \%)$ in $\mathrm{CdSe} /[2 \mathrm{Fe} 2 \mathrm{~S}]$ (Table S1). The fast component around $7 \mathrm{~ns}$ corresponds to the nonradiative recombination while the slow components may be assigned to radiative recombination, and both of these processes are related to the charge carrier depopulation from the defect states of the CdSe quantum dots. The almost identical photoluminescence kinetics between the two samples indicate the absence of charge transfer from the defect level of the CdSe quantum dots to the iron carbonyl cluster. When $\mathrm{g}-\mathrm{C}_{3} \mathrm{~N}_{4}$ is added to the system, the photoluminescence kinetics of the CdSe quantum dot defect emission decays much faster, which can be fitted by triexponential decays with time constants $\tau_{1}=$ $1.10 \pm 0.01 \mathrm{~ns}(63 \%), \tau_{2}=7.30 \pm 0.05 \mathrm{~ns}(30 \%)$, and $\tau_{3}=$ $59.05 \pm 0.36 \mathrm{~ns}(7 \%)$ for the $\mathrm{g}-\mathrm{C}_{3} \mathrm{~N}_{4} / \mathrm{CdSe}$ quantum dot/ $\left[\mathrm{Fe}_{2} \mathrm{~S}_{2}(\mathrm{CO})_{6}\right]$ composite (Table S1). The faster component with a lifetime of $1.10 \mathrm{~ns}$ indicates charge transfer from the defect states of the $\mathrm{CdSe}$ quantum dots to $\mathrm{g}-\mathrm{C}_{3} \mathrm{~N}_{4}$. At the probe wavelength for the intrinsic band edge emission of CdSe (i.e. $470 \mathrm{~nm}<\lambda<600 \mathrm{~nm}$ ), the photoluminescence kinetics can be fitted by triexponential decays with time constants $\tau_{1}=$ $0.61 \pm 0.01 \mathrm{~ns}(47 \%), \tau_{2}=4.92 \pm 0.02 \mathrm{~ns}(38 \%)$, and $\tau_{3}=$ $40.75 \pm 0.14 \mathrm{~ns}(15 \%)$ for the pure CdSe quantum dots and $\tau_{1}$ 
$=0.75 \pm 0.01 \mathrm{~ns}(51 \%), \tau_{2}=3.72 \pm 0.02 \mathrm{~ns}(41 \%)$, and $\tau_{3}=$ $38.09 \pm 0.36 \mathrm{~ns}(8 \%)$ for $\mathrm{g}-\mathrm{C}_{3} \mathrm{~N}_{4} / \mathrm{CdSe} /\left[\mathrm{Fe}_{2} \mathrm{~S}_{2}(\mathrm{CO})_{6}\right]$, but $\tau_{1}$ $=0.33 \pm 0.01 \mathrm{~ns}(66 \%), \tau_{2}=4.0 \pm 0.01 \mathrm{~ns}(26 \%)$ and $\tau_{3}=$ $44.16 \pm 0.10 \mathrm{~ns}(8 \%)$ for the CdSe quantum dot/iron carbonyl assembly (Table S2). For pure CdSe quantum dots, the fastest component with a lifetime of $0.61 \mathrm{~ns}$ represents the charge transfer from the band edge to the defect states as it is identical to the rise of the defect emission kinetics of the same sample (Figure S10), while the long lifetime around $40 \mathrm{~ns}$ refers to the intrinsic band edge radiative recombination. ${ }^{51,52}$ The middle component with a lifetime of around 4 ns refers to the interquantum dot energy transfer, which has been reported in a previous study. ${ }^{53}$ The photoluminescence decay of the CdSe quantum dot $/\left[\mathrm{Fe}_{2} \mathrm{~S}_{2}(\mathrm{CO})_{6}\right]$ assembly is faster than pure quantum dots due to the hole transfer from $\mathrm{CdSe}$ to the iron cluster. ${ }^{13}$ Furthermore, when carbon nitride was introduced to the system, the photoluminescence decay of the ternary system became slower than the binary system. One possible scenario is that the hole injection pathway to the $\left[\mathrm{Fe}_{2} \mathrm{~S}_{2}(\mathrm{CO})_{6}\right]$ complex is blocked or restricted by $\mathrm{g}-\mathrm{C}_{3} \mathrm{~N}_{4}$. As indicated by the XPS results (vide supra), the electronic interaction between $\mathrm{CdSe}$ and $\left[\mathrm{Fe}_{2} \mathrm{~S}_{2}(\mathrm{CO})_{6}\right]$ is not affected by the $\mathrm{g}-\mathrm{C}_{3} \mathrm{~N}_{4}$ addition and this reason may therefore be excluded. The only remaining interpretation is that there exists additional slow energy transfer, with a time constant around $0.7 \mathrm{~ns}$ from $\mathrm{g}-\mathrm{C}_{3} \mathrm{~N}_{4}$ to $\mathrm{CdSe}$ occurs, compensating the excited state depopulation in CdSe (Figure S11). Such energy transfer is feasible due to the large spectral overlap between the absorption of $\mathrm{CdSe}$ and the emission of $\mathrm{g}-\mathrm{C}_{3} \mathrm{~N}_{4}$ (Figure S12). In addition, as the excited electrons in $\mathrm{CdSe}$ are already long-lived, as verified by the transient absorption kinetics remaining almost constant within the detection window; such slow energy transfer may not cause a pronounced change in the transient absorption kinetics of the CdSe ground-state bleach.

Figure 8 summarizes all of the possible charge carrier dynamics after photoexcitation in our hybrid system (see the

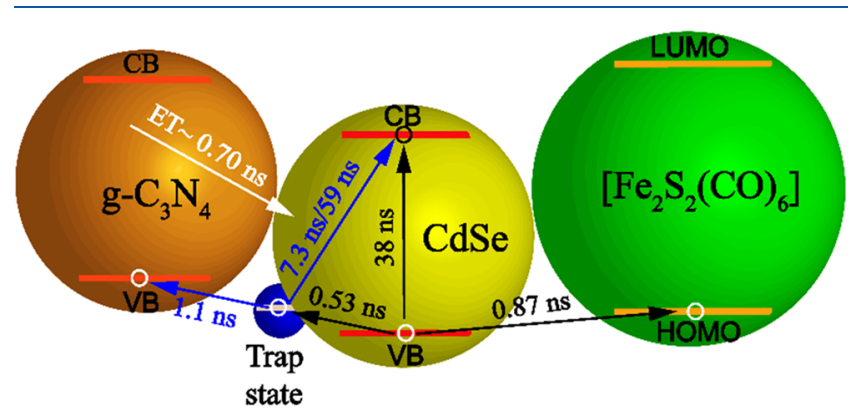

Figure 8. Recombination dynamics in the $\mathrm{g}-\mathrm{C}_{3} \mathrm{~N}_{4} / \mathrm{CdSe} /$ $\left[\mathrm{Fe}_{2} \mathrm{~S}_{2}(\mathrm{CO})_{6}\right]$ hybrid system: defect recombination (blue arrows), intrinsic recombination (black arrows), and energy transfer from g$\mathrm{C}_{3} \mathrm{~N}_{4}$ to $\mathrm{CdSe}$ quantum dots (white arrow). $\mathrm{VB}=$ valence band, $\mathrm{CB}=$ conduction band, ET = energy transfer.

Supporting Information for more details). Based on the relative energy levels of its individual components (vide supra, Figure $6)$, the $\mathrm{g}-\mathrm{C}_{3} \mathrm{~N}_{4} / \mathrm{CdSe}$ quantum dot $/\left[\mathrm{Fe}_{2} \mathrm{~S}_{2}(\mathrm{CO})_{6}\right]$ composite corresponds to a Type II heterojunction ${ }^{22}$ and shows excellent stability for photocatalytic hydrogen production. After all possible charge transfer and energy transfer between the three components in the composite, the photoexcited electrons finally remain in the quantum dots for proton reduction. In contrast, the roles of the iron carbonyl complex and $g-\mathrm{C}_{3} \mathrm{~N}_{4}$ are to mediate electron transfer from the sacrificial electron donor to scavenge the residual holes in the valence of the quantum dots. At the same time, the energy transfer from $\mathrm{g}-\mathrm{C}_{3} \mathrm{~N}_{4}$ to $\mathrm{CdSe}$ quantum dot/ $\left[\mathrm{Fe}_{2} \mathrm{~S}_{2}(\mathrm{CO})_{6}\right]$ assembly also contributes to the recombination process, i.e., g- $\mathrm{C}_{3} \mathrm{~N}_{4}$ can harvest more light and convert it into photogenerated charge carriers.

\section{CONCLUSIONS}

In conclusion, we have developed a new g- $\mathrm{C}_{3} \mathrm{~N}_{4} / \mathrm{CdSe}$ quantum dot $/\left[\mathrm{Fe}_{2} \mathrm{~S}_{2}(\mathrm{CO})_{6}\right]$ composite heterostructure for photocatalytic $\mathrm{H}_{2}$ evolution in water. It exhibits better stability and higher photocatalytic activity than the corresponding pure $\mathrm{CdSe}$ quantum dots, pure $\mathrm{g}-\mathrm{C}_{3} \mathrm{~N}_{4}$, or the related CdSe quantum dot $/\left[\mathrm{Fe}_{2} \mathrm{~S}_{2}(\mathrm{CO})_{6}\right]$ assembly. Photophysical studies via transient absorption and time-resolved photoluminescence spectroscopies clearly illustrate the charge transfer dynamics in the $\mathrm{g}-\mathrm{C}_{3} \mathrm{~N}_{4}$-based composites. We found extra hole transfer processes from the defect states of the excited CdSe quantum dots to the $\mathrm{g}-\mathrm{C}_{3} \mathrm{~N}_{4}$ in the ternary composites compared with the binary system; the hole transfer significantly inhibits the recombination of photogenerated charge carriers. Graphitic carbon nitride can also harvest light and efficiently transfer energy to the $\mathrm{CdSe}$ quantum dots to enhance the photocatalytic activity for hydrogen generation. The $\mathrm{g}-\mathrm{C}_{3} \mathrm{~N}_{4}$ support/matrix confers greater stability and efficiency to the CdSe quantum dots/iron carbonyl cluster assembly in the photocatalytic hydrogen evolution process.

\section{ASSOCIATED CONTENT}

\section{Supporting Information}

The Supporting Information is available free of charge at https://pubs.acs.org/doi/10.1021/acsanm.1c01096.

Energy-dispersive X-ray spectra; powder X-ray diffraction patterns; BET analysis; X-ray photoelectron spectra (XPS); TEM images; photoluminescence, time-resolved photoluminescence (TRPL), and UV-vis spectra; photocatalytic hydrogen evolution data; and a table of multiexponential fitting parameters (PDF)

\section{AUTHOR INFORMATION}

\section{Corresponding Authors}

Kaibo Zheng - Division of Chemical Physics, Department of Chemistry, Lund University, SE-221 00 Lund, Sweden; Department of Chemistry, Technical University of Denmark, DK-2800 Kongens Lyngby, Denmark; ○ orcid.org/00000002-7236-1070; Email: Kaibo.Zheng@chemphys.lu.se

Ebbe Nordlander - Division of Chemical Physics, Department of Chemistry, Lund University, SE-221 00 Lund, Sweden; - orcid.org/0000-0001-9575-4929;

Email: Ebbe.Nordlander@chemphys.lu.se

\section{Authors}

Chuanshuai Li - Division of Chemical Physics, Department of Chemistry, Lund University, SE-221 00 Lund, Sweden

Xianshao Zou - Division of Chemical Physics, Department of Chemistry, Lund University, SE-221 00 Lund, Sweden

Weihua Lin - Division of Chemical Physics, Department of Chemistry, Lund University, SE-221 00 Lund, Sweden

Hassan Mourad - Division of Chemical Physics, Department of Chemistry, Lund University, SE-221 00 Lund, Sweden 
Jie Meng - Department of Chemistry, Technical University of Denmark, DK-2800 Kongens Lyngby, Denmark; () orcid.org/0000-0002-3813-5221

Yang Liu - Division of Chemical Physics, Department of Chemistry, Lund University, SE-221 00 Lund, Sweden

Mohamed Abdellah - Division of Chemical Physics, Department of Chemistry, Lund University, SE-22100 Lund, Sweden

Meiyuan Guo - Division of Chemical Physics, Department of Chemistry, Lund University, SE-221 00 Lund, Sweden

Complete contact information is available at:

https://pubs.acs.org/10.1021/acsanm.1c01096

\section{Notes}

The authors declare no competing financial interest.

\section{ACKNOWLEDGMENTS}

C.L. thanks the Chinese Scholarship Council for a predoctoral fellowship. K.Z. thanks the financial support from Independent Research Fund Denmark-Nature Sciences (DFF-FNU, Project no. DFF-7014-00302), Independent Research Fund DenmarkSapere Aude starting grant (no. 7026-00037A), and Swedish Research Council VR starting grant (no. 2017-05337). C.L. and E.N. thank the Sten K. Johnson Foundation for financial support. The authors thank Qinying Pan and Huili Cao for assistance with XPS and BET measurements and Jens Uhlig for valuable discussions.

\section{REFERENCES}

(1) Fujishima, A.; Honda, K. Electrochemical Photolysis of Water at a Semiconductor Electrode. Nature 1972, 238, 37-38.

(2) Voiry, D.; Shin, H. S.; Loh, K. P.; Chhowalla, M. LowDimensional Catalysts for Hydrogen Evolution and $\mathrm{CO}_{2}$ Reduction. Nat. Rev. Chem. 2018, 2, No. 0105.

(3) Mahler, B.; Hoepfner, V.; Liao, K.; Ozin, G. A. Colloidal Synthesis of $1 \mathrm{~T}-\mathrm{WS}_{2}$ and $2 \mathrm{H}-\mathrm{WS}_{2}$ Nanosheets: Applications for Photocatalytic Hydrogen Evolution. J. Am. Chem. Soc. 2014, 136, 14121-14127.

(4) Han, Q.; Wang, B.; Gao, J.; Cheng, Z.; Zhao, Y.; Zhang, Z.; Qu, L. Atomically Thin Mesoporous Nanomesh of Graphitic $\mathrm{C}_{3} \mathrm{~N}_{4}$ for High-Efficiency Photocatalytic Hydrogen Evolution. ACS Nano 2016, $10,2745-2751$.

(5) Wasielewski, M. R. Photoinduced Electron Transfer in Supramolecular Systems for Artificial Photosynthesis. Chem. Rev. 1992, 92, 435-461.

(6) Kubacka, A.; Fernandez-Garcia, M.; Colon, G. Advanced Nanoarchitectures for Solar Photocatalytic Applications. Chem. Rev. 2012, 112, 1555-1614.

(7) Marschall, R. Semiconductor Composites: Strategies for Enhancing Charge Carrier Separation to Improve Photocatalytic Activity. Adv. Funct. Mater. 2014, 24, 2421-2440.

(8) Sun, L.; Åkermark, B.; Ott, S. Iron Hydrogenase Active Site Mimics in Supramolecular Systems Aiming for Light-Driven Hydrogen Production. Coord. Chem. Rev. 2005, 249, 1653-1663.

(9) Wang, F.; Wang, W.-G.; Wang, H.-Y.; Si, G.; Tung, C.-H.; Wu, L.-Z. Artificial Photosynthetic Systems Based on [FeFe]-Hydrogenase Mimics: the Road to High Efficiency for Light-Driven Hydrogen Evolution. ACS Catal. 2012, 2, 407-416.

(10) Rauchfuss, T. B. Diiron Azadithiolates as Models for the [FeFe]-Hydrogenase Active Site and Paradigm for the Role of the Second Coordination Sphere. Acc. Chem. Res. 2015, 48, 2107-2116.

(11) Wu, L.-Z.; Chen, B.; Li, Z.-J.; Tung, C.-H. Enhancement of the Efficiency of Photocatalytic Reduction of Protons to Hydrogen via Molecular Assembly. Acc. Chem. Res. 2014, 47, 2177-2185.

(12) Li, C.-B.; Li, Z.-J.; Yu, S.; Wang, G.-X.; Wang, F.; Meng, Q.-Y.; Chen, B.; Feng, K.; Tung, C.-H.; Wu, L.-Z. Interface-Directed
Assembly of a Simple Precursor of $[\mathrm{FeFe}]-\mathrm{H}_{2}$ ase Mimics on CdSe QDs for Photosynthetic Hydrogen Evolution in Water. Energy Environ. Sci. 2013, 6, 2597-2602.

(13) Li, C.; Rahaman, A.; Lin, W.; Mourad, H.; Meng, J.; Honarfar, A.; Abdellah, M.; Guo, M.; Richmond, M. G.; Zheng, K.; Nordlander, E. Electron Transfer Mediated by Iron Carbonyl Clusters Enhance Light-Driven Hydrogen Evolution in Water by Quantum Dots. ChemSusChem 2020, 13, 3252-3260.

(14) Liang, W. J.; Wang, F.; Wen, M.; Jian, J. X.; Wang, X. Z.; Chen, B.; Tung, C. H.; Wu, L. Z. Branched Polyethylenimine Improves Hydrogen Photoproduction from a CdSe Quantum Dot/[FeFe]Hydrogenase Mimic System in Neutral Aqueous Solutions. Chem. Eur. J. 2015, 21, 3187-3192.

(15) Cheng, M.; Wang, M.; Zhang, S.; Liu, F.; Yang, Y.; Wan, B.; Sun, L. Photocatalytic $\mathrm{H}_{2}$ Production Using a Hybrid Assembly of an $[\mathrm{FeFe}]-$ Hydrogenase Model and CdSe Quantum Dot Linked through a Thiolato-Functionalized Cyclodextrin. Faraday Discuss. 2017, 198, 197-209.

(16) Peng, Y.; Shang, L.; Bian, T.; Zhao, Y.; Zhou, C.; Yu, H.; Wu, L.-Z.; Tung, C.-H.; Zhang, T. Flower-Like CdSe Ultrathin Nanosheet Assemblies for Enhanced Visible-Light-Driven Photocatalytic $\mathrm{H}_{2}$ Production. Chem. Commun. 2015, 51, 4677-4680.

(17) Han, J.; Dai, F.; Liu, Y.; Zhao, R.; Wang, L.; Feng, S. Synthesis of $\mathrm{CdSe} / \mathrm{SrTiO}_{3}$ Nanocomposites with Enhanced Photocatalytic Hydrogen Production Activity. Appl. Surf. Sci. 2019, 467-468, 1033-1039.

(18) Wen, J.; Xie, J.; Chen, X.; Li, X. A Review on g- $\mathrm{C}_{3} \mathrm{~N}_{4}-$ Based Photocatalysts. Appl. Surf. Sci. 2017, 391, 72-123.

(19) Ren, Y.; Zeng, D.; Ong, W.-J. Interfacial Engineering of Graphitic Carbon Nitride $\left(\mathrm{g}-\mathrm{C}_{3} \mathrm{~N}_{4}\right)$-Based Metal Sulfide Heterojunction Photocatalysts for Energy Conversion: a Review. Chin. J. Catal. 2019, 40, 289-319.

(20) Liao, G.; Gong, Y.; Zhang, L.; Gao, H.; Yang, G.-J.; Fang, B. Semiconductor Polymeric Graphitic Carbon Nitride Photocatalysts: the "Holy Grail" for the Photocatalytic Hydrogen Evolution Reaction under Visible Light. Energy Environ. Sci. 2019, 12, 2080-2147.

(21) Gong, Y.; Li, M.; Li, H.; Wang, Y. Graphitic Carbon Nitride Polymers: Promising Catalysts or Catalyst Supports for Heterogeneous Oxidation and Hydrogenation. Green Chem. 2015, 17, 715736.

(22) Ong, W.-J.; Tan, L.-L.; Ng, Y. H.; Yong, S.-T.; Chai, S.-P. Graphitic Carbon Nitride $\left(\mathrm{g}-\mathrm{C}_{3} \mathrm{~N}_{4}\right)$-Based Photocatalysts for Artificial Photosynthesis and Environmental Remediation: Are We a Step Closer to Achieving Sustainability? Chem. Rev. 2016, 116, 71597329.

(23) Zheng, D.; zhang, G.; Wang, X. Integrating CdS Quantum Dots on Hollow Graphitic Carbon Nitride Nanospheres for Hydrogen Evolution Photocatalysis. Appl. Catal., B 2015, 179, 479-488.

(24) Liu, Y.; Yan, K.; Zhang, J. Graphitic Carbon Nitride Sensitized with CdS Quantum Dots for Visible-Light-Driven Photoelectrochemical Aptasensing of Tetracycline. ACS Appl. Mater. Interfaces 2016, 8, 28255-28264.

(25) Zou, Y.; Shi, J. W.; Ma, D.; Fan, Z.; Cheng, L.; Sun, D.; Wang, Z.; Niu, C. $\mathrm{WS}_{2} /$ Graphitic Carbon Nitride Heterojunction Nanosheets Decorated with CdS Quantum Dots for Photocatalytic Hydrogen Production. ChemSusChem 2018, 11, 1187-1197.

(26) Vattikuti, S. V.; Reddy, P. A. K.; Shim, J.; Byon, C. VisibleLight-Driven Photocatalytic Activity of $\mathrm{SnO}_{2}-\mathrm{ZnO}$ Quantum Dots Anchored on $\mathrm{g}-\mathrm{C}_{3} \mathrm{~N}_{4}$ Nanosheets for Photocatalytic Pollutant Degradation and $\mathrm{H}_{2}$ Production. ACS Omega 2018, 3, 7587-7602.

(27) Marchal, C.; Cottineau, T.; Méndez-Medrano, M. G.; ColbeauJustin, C.; Caps, V.; Keller, V. $\mathrm{Au} / \mathrm{TiO}_{2}-\mathrm{g}-\mathrm{C}_{3} \mathrm{~N}_{4}$ Nanocomposites for Enhanced Photocatalytic $\mathrm{H}_{2}$ Production from Water under Visible Light Irradiation with Very Low Quantities of Sacrificial Agents. Adv. Energy Mater. 2018, 8, No. 1702142.

(28) Zhong, Y.; Chen, W.; Yu, S.; Xie, Z.; Wei, S.; Zhou, Y. CdSe Quantum Dots $/ \mathrm{g}-\mathrm{C}_{3} \mathrm{~N}_{4}$ Heterostructure for Efficient $\mathrm{H}_{2}$ Production under Visible Light Irradiation. ACS Omega 2018, 3, 17762-17769. 
(29) Han, H.-Y.; Sheng, Z.-H.; Liang, J.-G. A Novel Method for the Preparation of Water-Soluble and Small-Size CdSe Quantum Dots. Mater. Lett. 2006, 60, 3782-3785.

(30) Bose, K.; Sinn, E.; Averill, B. Synthesis and X-ray Structure of the $\left[\mathrm{Fe}_{4} \mathrm{~S}_{4}(\mathrm{CO})_{12}\right]_{2}$-Ion: an Example of Intermolecular Disulfide Formation by the (.mu. $-\mathrm{S})_{2} \mathrm{Fe}_{2}(\mathrm{CO})_{6}$ Unit. Organometallics 1984, 3 , $1126-1128$.

(31) Wang, W.; Jimmy, C. Y.; Shen, Z.; Chan, D. K.; Gu, T. G-C $\mathrm{C}_{3} \mathrm{~N}_{4}$ Quantum Dots: Direct Synthesis, Upconversion Properties and Photocatalytic Application. Chem. Commun. 2014, 50, 10148-10150.

(32) Sun, L.; Qi, Y.; Jia, C.-J.; Jin, Z.; Fan, W. Enhanced VisibleLight Photocatalytic Activity of g- $\mathrm{C}_{3} \mathrm{~N}_{4} / \mathrm{Zn}_{2} \mathrm{GeO}_{4}$ Heterojunctions with Effective Interfaces Based on Band Match. Nanoscale 2014, 6, 2649-2659.

(33) Wagner, A. J.; Wolfe, G. M.; Fairbrother, D. H. Reactivity of Vapor-Deposited Metal Atoms with Nitrogen-Containing Polymers and Organic Surfaces Studied by in Situ XPS. Appl. Surf. Sci. 2003, 219, 317-328.

(34) Jiang, F.; Yan, T.; Chen, H.; Sun, A.; Xu, C.; Wang, X. A g$\mathrm{C}_{3} \mathrm{~N}_{4}-\mathrm{CdS}$ Composite Catalyst with High Visible-Light-Driven Catalytic Activity and Photostability for Methylene Blue Degradation. Appl. Surf. Sci. 2014, 295, 164-172.

(35) Wang, K.; Li, J.; Zhang, G. Ag-Bridged Z-Scheme 2D/2D $\mathrm{Bi}_{5} \mathrm{FeTi}_{3} \mathrm{O}_{15} / \mathrm{g}-\mathrm{C}_{3} \mathrm{~N}_{4}$ Heterojunction for Enhanced Photocatalysis: Mediator-Induced Interfacial Charge Transfer and Mechanism Insights. ACS Appl. Mater. Interfaces 2019, 11, 27686-27696.

(36) Hu, D.-H.; Wu, H.-M.; Liang, J.-G.; Han, H.-Y. Study on the Interaction Between CdSe Quantum Dots and Hemoglobin. Spectrochim. Acta, Part A 2008, 69, 830-834.

(37) Krylova, V.; Dukštiene, N. The Structure of PA-Se-S-Cd Composite Materials Probed with FTIR Spectroscopy. Appl. Surf. Sci. 2019, 470, 462-471.

(38) Neeleshwar, S.; Chen, C.; Tsai, C.; Chen, Y.; Chen, C. C.; Shyu, S.; Seehra, M. Size-Dependent Properties of CdSe Quantum Dots. Phys. Rev. B 2005, 71, No. 201307.

(39) Elbanna, O.; Fujitsuka, M.; Majima, T. G- $\mathrm{C}_{3} \mathrm{~N}_{4} / \mathrm{TiO}_{2}$ Mesocrystals Composite for $\mathrm{H}_{2}$ Evolution under Visible-Light Irradiation and its Charge Carrier Dynamics. ACS Appl. Mater. Interfaces 2017, 9, 34844-34854.

(40) Zhang, J.-R.; Ma, Y.; Wang, S.-Y.; Ding, J.; Gao, B.; Kan, E.; Hua, W. Accurate K-edge X-ray Photoelectron and Absorption Spectra of $\mathrm{g}^{-} \mathrm{C}_{3} \mathrm{~N}_{4}$ Nanosheets by First-Principles Simulations and Reinterpretations. Phys. Chem. Chem. Phys. 2019, 21, 22819-22830.

(41) Fu, J.; Chang, B.; Tian, Y.; Xi, F.; Dong, X. Novel $\mathrm{C}_{3} \mathrm{~N}_{4}-\mathrm{CdS}$ Composite Photocatalysts with Organic-Inorganic Heterojunctions: in Situ Synthesis, Exceptional Activity, High Stability and Photocatalytic Mechanism. J. Mater. Chem. A 2013, 1, 3083-3090.

(42) Abdellah, M.; Karki, K. J.; Lenngren, N.; Zheng, K.; Pascher, Tr.; Yartsev, A.; Pullerits, T. Ultra Long-Lived Radiative Trap States in CdSe Quantum Dots. J. Phys. Chem. C 2014, 118, 21682-21686.

(43) Liu, Y.-N.; Zhou, X.; Shen, C.-C.; Zhao, Z.-W.; Jiang, Y.-F.; Ma, L.-B.; Fang, X.-X.; Akif, Z.; Cheag, T.-Y.; Xu, A.-W. HydrogenBonding-Assisted Charge Transfer: Significantly Enhanced Photocatalytic $\mathrm{H}_{2}$ Evolution over g- $\mathrm{C}_{3} \mathrm{~N}_{4}$ Anchored with Ferrocene-Based Hole Relay. Catal. Sci. Technol. 2018, 8, 2853-2859.

(44) Wang, X.; Maeda, K.; Thomas, A.; Takanabe, K.; Xin, G.; Carlsson, J. M.; Domen, K.; Antonietti, M. A Metal-Free Polymeric Photocatalyst for Hydrogen Production from Water under Visible Light. Nat. Mater. 2009, 8, 76-80.

(45) Yang, P.; Zhao, J.; Qiao, W.; Li, L.; Zhu, Z. Ammonia-Induced Robust Photocatalytic Hydrogen Evolution of Graphitic Carbon Nitride. Nanoscale 2015, 7, 18887-18890.

(46) Islam, S. K.; Sohel, M. A.; Lombardi, J. R. Coupled Exciton and Charge-Transfer Resonances in the Raman Enhancement of Phonon Modes of CdSe Quantum Dots (QDs). J. Phys. Chem. C 2014, 118, 19415-19421.

(47) Liu, X.-Y.; Zheng, H.-W.; Zhang, Z.-L.; Liu, X.-S.; Wan, R.-Q.; Zhang, W.-F. Effect of Energy Level Matching on the Enhancement of
Photovoltaic Response about Oxide/ $\mathrm{Zn}_{2} \mathrm{SnO}_{4}$ Composites. J. Mater. Chem. 2011, 21, 4108-4116.

(48) Khnayzer, R.; Thoi, V.; Nippe, M.; King, A.; Jurss, J.; El Roz, K.; Long, J.; Chang, C.; Castellano, F. Towards a Comprehensive Understanding of Visible-Light Photogeneration of Hydrogen from Water Using Cobalt (II) Polypyridyl Catalysts. Energy Environ. Sci. 2014, 7, 1477-1488.

(49) Zheng, K.; Žídek, K.; Abdellah, M.; Zhang, W.; Chábera, P.; Lenngren, N.; Yartsev, A.; Pullerits, Tn. Ultrafast Charge Transfer from CdSe Quantum Dots to p-type NiO: Hole Injection vs Hole Trapping. J. Phys. Chem. C 2014, 118, 18462-18471.

(50) Zidek, K.; Zheng, K.; Ponseca, C. S., Jr; Messing, M. E.; Wallenberg, L. R.; Chábera, P.; Abdellah, M.; Sundström, V.; Pullerits, T. Electron Transfer in Quantum-Dot-Sensitized $\mathrm{ZnO}$ Nanowires: Ultrafast Time-Resolved Absorption and Terahertz Study. J. Am. Chem. Soc. 2012, 134, 12110-12117.

(51) Javier, A.; Magana, D.; Jennings, T.; Strouse, G. F. Nanosecond Exciton Recombination Dynamics in Colloidal CdSe Quantum Dots under Ambient Conditions. Appl. Phys. Lett. 2003, 83, 1423-1425.

(52) Califano, M.; Franceschetti, A.; Zunger, A. Lifetime and Polarization of the Radiative Decay of Excitons, Biexcitons, and Trions in CdSe Nanocrystal Quantum Dots. Phys. Rev. B 2007, 75 , No. 115401.

(53) Zheng, K.; Zidek, K.; Abdellah, M.; Torbjörnsson, M.; Chabera, P.; Shao, S.; Zhang, F.; Pullerits, T. Fast Monolayer Absorption and Slow Energy Transfer in CdSe Quantum Dot Sensitized $\mathrm{ZnO}$ Nanowires. J. Phys. Chem. A 2013, 117, 5919-5925. 